\title{
Soil Microbiota of Dystric Cambisol in the High Tatra Mountains (Slovakia) after Windthrow
}

\author{
Alexandra Šimonovičová ${ }^{1}$, Lucia Kraková ${ }^{2}$, Elena Piecková ${ }^{3}$, Matej Planý ${ }^{2}$, Mária Globanová ${ }^{3}$, \\ Eva Pauditšová ${ }^{4}$, Katarína Šoltys ${ }^{5}$, Jaroslav Budiš ${ }^{5}$, Tomáš Szemes ${ }^{5}$, Jana Gáfriková ${ }^{1}$ and \\ Domenico Pangallo $2, *$ (i) \\ 1 Department of Soil Science, Faculty of Natural Sciences, Comenius University in Bratislava, \\ 84215 Bratislava, Slovakia; alexandra.simonovicova@uniba.sk (A.Š.); gafrikova4@uniba.sk (J.G.) \\ 2 Institute of Molecular Biology, Slovak Academy of Sciences, 84551 Bratislava, Slovakia; \\ lucia.krakova@savba.sk (L.K.); matejpln@gmail.com (M.P.) \\ 3 Faculty of Medicine, Slovak Medical University, 83303 Bratislava, Slovakia; elena.pieckova@szu.sk (E.P.); \\ majorosova@gmail.com (M.G.) \\ 4 Department of Landscape Ecology, Faculty of Natural Sciences, Comenius University in Bratislava, \\ 84215 Bratislava, Slovakia; epaudits@gmail.com \\ 5 Science Park, Comenius University in Bratislava, 84104 Bratislava, Slovakia; \\ katarina.soltys@gmail.com (K.Š.); jaroslav.budis@gmail.com (J.B.); tomasszemes@gmail.com (T.S.) \\ * Correspondence: domenico.pangallo@savba.sk
}

Received: 10 October 2019; Accepted: 22 November 2019; Published: 2 December 2019

\begin{abstract}
There has been much more damage to forests in the Slovak Republic in the second half of the 20th century than to other European countries. Forested mountain massifs have become a filter of industrial and transportation emissions from abroad, as well as from domestic origins. There are not only acidic deposits of sulphur and heavy metals present in forest soils, but other additional environmental problems, such as climate change, storms, fires, floods, droughts, are worsening the situation. Therefore, forest terrestrial ecosystems are becoming more vulnerable due to changes in natural and environmental conditions. In the High Tatra Mountains in Slovakia, which are protected as a national park, four internationally monitored localities were established after the windthrow disaster in 2004 and fire in 2005: REF, with intact forest; EXT, with extracted wood mass; NEX, with non-extracted wood mass; and FIR, the burnt locality. Soils from these localities were microbiologically analysed with special attention to fungi. Bacterial microbiota detected by high-throughput sequencing showed the prevalence of the genera Acidothermus, Mycobacterium, and Nocardia, and a very low presence of the genera Acidibacter, Burkholderia-Paraburkholderia, Optitus and the uncultured genus Desulfurellaceae H16 in the soil sample from the burnt locality when compared with the unburned sites. Additionally, soil mycocoenoses showed a low similarity between the locality with an intact forest ecosystem and the localities with extracted (REF-EXT) and non-extracted (REF-NEX) wood mass. There was no similarity with the burnt locality (FIR), where heat-resistant fungi dominated. It was shown that the windthrow disaster and subsequent extraction or non-extraction of wood mass did not affect the soil microbial communities or their development. On the other hand, the influence of fire was significant.
\end{abstract}

Keywords: high-throughput sequencing; soil microbial communities; dystric cambisol; windthrow; fire

\section{Introduction}

Forest ecosystems worldwide are damaged by a variety of agents, resulting in the destruction of individual trees and sometimes the decline of entire forest complexes [1]. Extreme events such as 
storms, flooding, droughts, and heatwaves, together with anthropogenic interventions, are considered to be the most perilous threats in many European regions. In the past few decades, climate change has been recognized as one of the most serious challenges facing the world. As a consequence, all terrestrial ecosystems are becoming more vulnerable due to changes in natural and environmental conditions. The loss of ecological functions in forest terrestrial ecosystems is a very sensitive topic, especially in protected areas with a high level of nature conservation [2], such as the High Tatras National Park in Slovakia. The climate variation influences the adaptive capacity of the ecosystem to respond to potential impacts, as well as its sensitivity [3,4].

Among all terrestrial ecosystems, forests are especially exposed to windstorms, fire, harvesting, insect outbreaks, and pathogen infections, which can significantly modify forest soil carbon dynamics [5]. Wind is the most detrimental factor in European forest ecosystems. For instance, a storm in Gudurn in southern Sweden in January 2005 caused economic damage of 2.4 billion euros in total [6]; however, the social and environmental costs have not been reported. The increased number, size, and severity of forest fires as a result of recent climatic changes has been reported across Europe. The area of land affected by wildfires in Europe in 2014 was estimated to be 83,809 ha [7]. In 2017, the area of burnt regions increased, and in European countries fires covered 1,004,407 ha [8]. Windstorms and wildfires have several ecological and environmental impacts. Both have lasting effects on the composition of the microbial community, cause losses in the canopy or herb layers, and decrease the quantity and quality of soil organic matter $[9,10]$.

Forest stands and aboveground vegetation are crucial for sustaining appropriate soil conditions. Aboveground (foliage) and belowground (fine roots) litter from dead trees serve as a source of nutrients, improve microclimate conditions and, via root systems, help to improve soil aeration and aggregate formation. Additionally, litter enhances the mineralization of organic matter, which serves as a source of energy and is considered to be a principal pool of carbon and other nutrients for soil microorganisms $[11,12]$. Soil microbiota is fundamental for supporting a healthy and vital forest ecosystem. By studying the impact of disturbances, as well as how community composition influences ecosystem functioning, it is possible to evaluate the response and progress of the microbial community in a changing environment [13].

The forest is a natural element in the Tatra Mountains that covers almost 60,000 ha on both their Slovak and Polish sides. The Tatra Mountains are the highest part of the Carpathian mountain range and are considered to be a "geographic island" due to their altitude and geomorphological constellation. Because of this island effect, strong winds often take place, frequently reaching speeds of more than $10 \mathrm{~m} / \mathrm{s}$. After several windstorms in the 1920s, a large area was systematically forested. From the 1920 s to the 1980s, the Tatra forest suffered several natural disturbances, such as windstorms, wildfires, and insect calamities [14-16]. At the beginning of the 20th century, an area of 12,000 ha in the Tatra National Park was seriously damaged by northern winds called bora. Bora is a type of katabatic wind with a northern to northeastern direction and high velocities, which exceeded $200 \mathrm{~km} / \mathrm{h}$ in November 2004. The following year, a part of the damaged area of about 220 ha was affected by wildfire [17]. In the last few years, the intensity and occurrence of such natural events have increased. It remains unclear whether the more frequent occurrence of windstorms is a consequence of climate change.

In November 2004, forests on the south-oriented slopes were heavily damaged by bora winds. Cold downslope winds with speeds exceeding $230 \mathrm{~km} / \mathrm{h}$ destroyed 12,000 ha ( 2.3 million $\mathrm{m}^{3}$ ) of spruce forest. According to the area and the amount of wood involved, it was the biggest natural calamity ever documented in Slovakia and the surrounding countries. The disaster is counted among the 10 most terrible European wind calamities over the last 30 years [18]. At four internationally monitored localities (Figure 1), systematic ecological observations from many research fields were initiated to monitor climate and land-use changes [19], water repellence of forest soils [20], soil properties in relation to the determination of organic fractions and enzymatic activity [21], soil microbiology and microbial diversity [22,23], plant community structure and changes in vegetation cover [24], tree-ring reconstruction [25] and soil fauna changes [26]. 


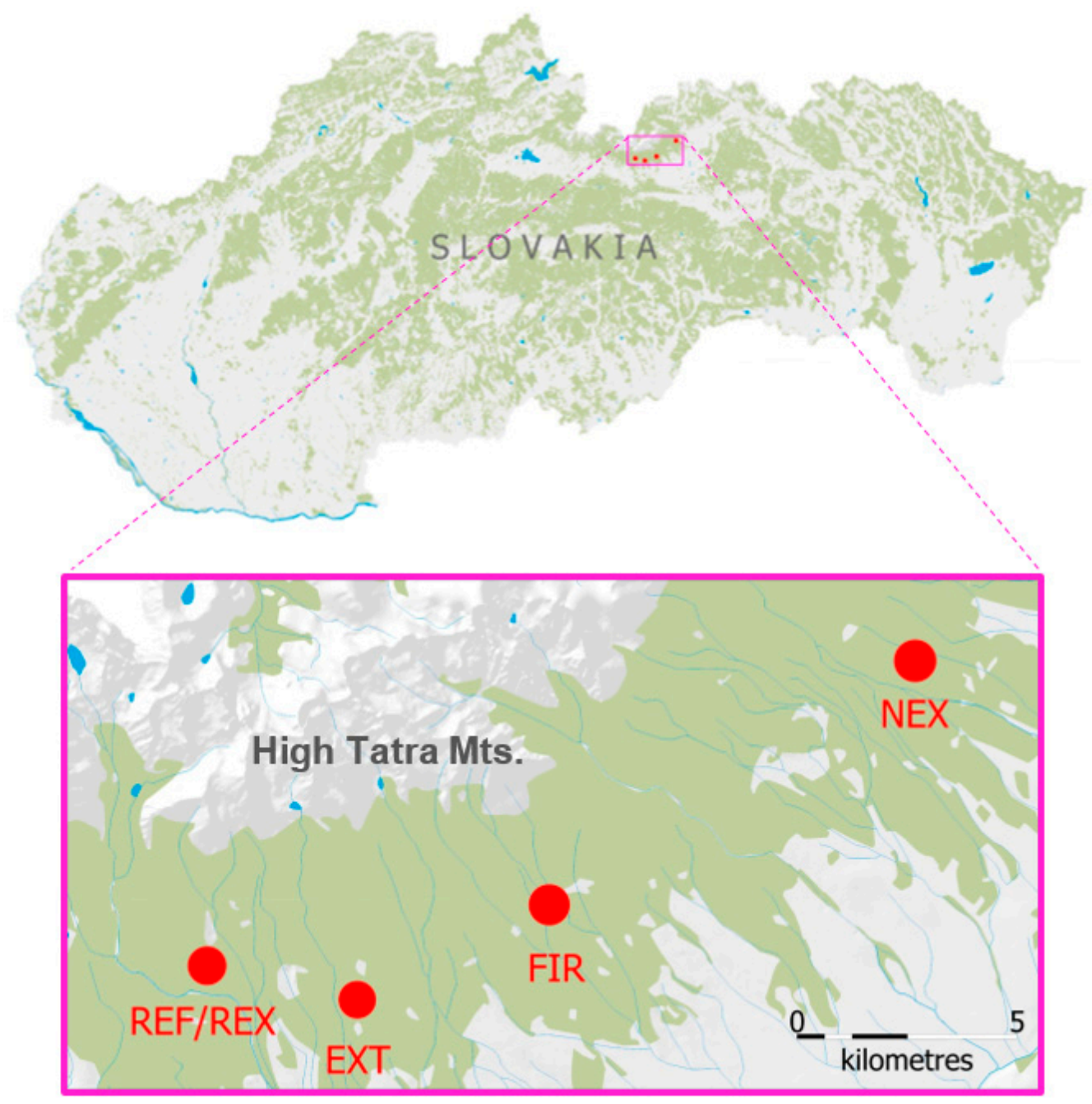

Figure 1. Internationally monitored localities in the High Tatra Mountains in Slovakia established after the windthrow in 2004 and fire in 2005. (Map source: https://geo.enviroportal.sk/atlassr. Author: E. Pauditšová, 2019). Legend: REF-reference locality; REX—in 2014 the reference locality was destroyed by windthrow; therefore, the locality was remarked as reference and extracted locality; EXT_locality with extracted wood mass after the windthrow; NEX-locality with non-extracted wood mass after the windthrow which left for self-regeneration; FIR-locality where, after the windthrow, the fire followed in 2005.

There is much to be gained from interdisciplinary communication about the nature and consequences of recurrent wind damage [27]. The aim of our study was to evaluate the impact on soil microbiomes of different forest management techniques after the windthrow and fire, compared with an intact forest soil environment, used as reference. Our investigation was focused especially on soil fungi using high-throughput sequencing together with traditional cultivation methods.

\section{Materials and Methods}

\subsection{Study Sites and Soil Sampling}

Soil samples were collected at four internationally monitored research localities (Table 1 and Figure 2) of about $30 \mathrm{~m} \times 30 \mathrm{~m}$. The first locality, REF (reference), is a site near Vyšné Hágy with an intact forest ecosystem and was selected for comparison. In 2014, its forest ecosystem was destroyed by a windthrow event with lower intensity than that of 2004, and the locality REF was subsequently renamed to REX (reference and extracted). The second locality, EXT (extracted), located near Danielov 
Dom, is a site with extracted wood mass after the windthrow of 2004. The third locality, NEX (non-extracted), near Tatranská Lomnica-Jamy, has non-extracted wood mass after the windthrow left for self-regeneration. The fourth locality, FIR (fire), near Tatranské Zruby, was damaged by the fire in 2005 after the windthrow of the previous year [17].
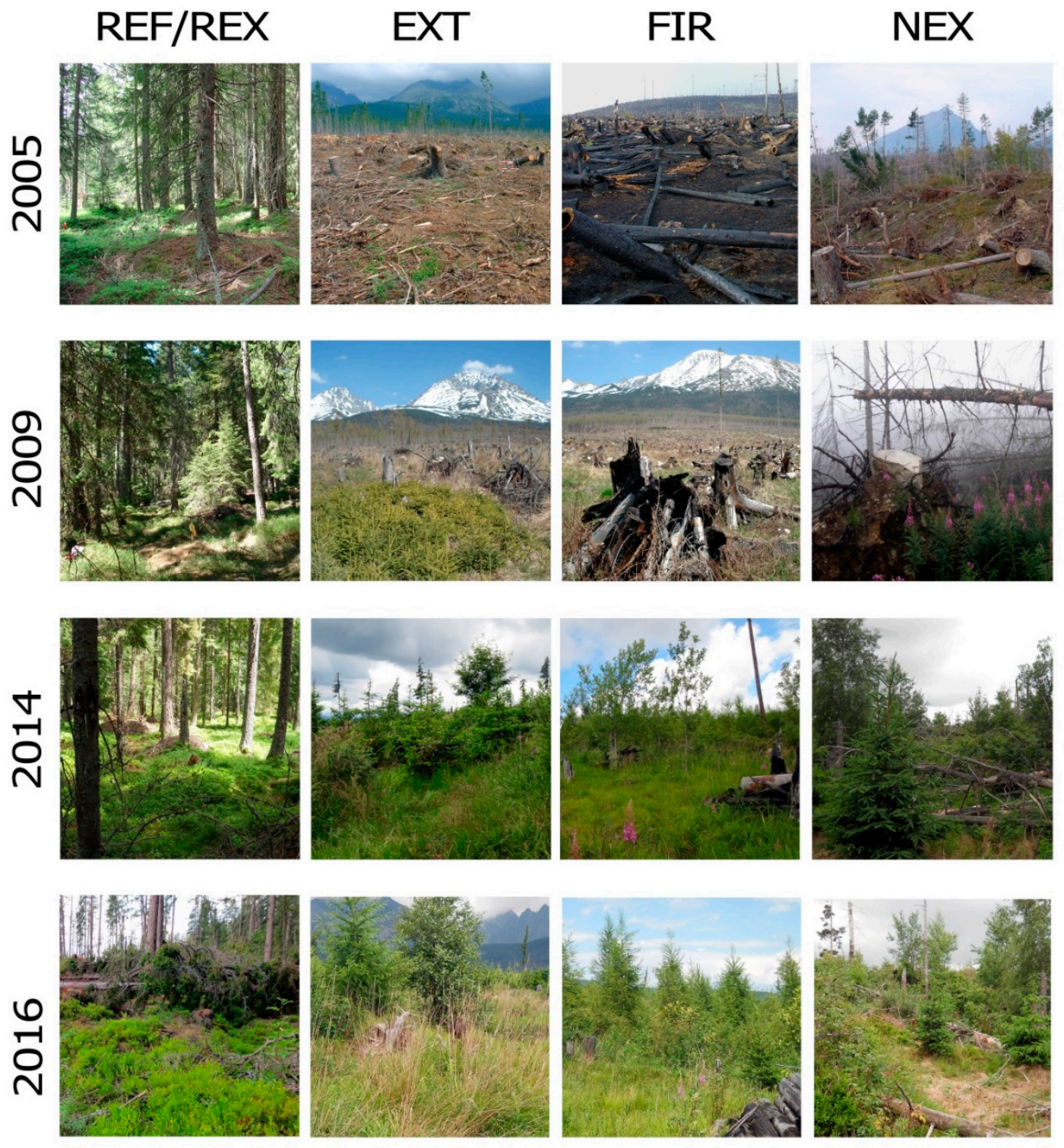

Figure 2. Heavily damaged forest areas in the High Tatra Mountains by bora winds (Photos: A. Šimonovičová 2005, 2009, and 2014, J. Gáfriková 2016). Legend: REF-reference locality; REX-in 2014, the reference locality was destroyed by windthrow; therefore, in 2016, the locality was remarked as reference and extracted locality; EXT-locality with extracted wood mass after the windthrow; NEX-locality with non-extracted wood mass after the windthrow, which was left for self-regeneration; FIR-locality where, after the windthrow, the fire followed in 2005. 
Table 1. Characteristic at monitored localities and soil characteristics in the High Tatra Mountains.

\begin{tabular}{|c|c|c|c|c|}
\hline $\begin{array}{l}\text { Monitored } \\
\text { Localities }\end{array}$ & REF & EXT & NEX & FIR \\
\hline \multirow{2}{*}{ GPS localization } & $\mathrm{N} 49^{\circ} 07^{\prime} 17.5^{\prime \prime}$ & $\mathrm{N} 49^{\circ} 07^{\prime} 11.9^{\prime \prime}$ & N49 $09^{\prime} 36.3^{\prime \prime}$ & N49 $07^{\circ} 49.7^{\prime \prime}$ \\
\hline & $\mathrm{E} 20^{\circ} 06^{\prime} 16.4^{\prime \prime}$ & $\mathrm{E} 20^{\circ} 09^{\prime} 47.6^{\prime \prime}$ & $\mathrm{E} 20^{\circ} 15^{\prime} 08.8^{\prime \prime}$ & $\mathrm{E} 20^{\circ} 11^{\prime} 57.3^{\prime \prime}$ \\
\hline altitude (a.s.1.) & 1100-1250 & 1040-1260 & 1050-1150 & 1000-1200 \\
\hline soil type & Dystric Cambisol & Dystric Cambisol & Dystric Cambisol & Dystric Cambisol \\
\hline geology & $\begin{array}{l}\text { moraine } \\
\text { mindel-riss }\end{array}$ & $\begin{array}{c}\text { moraine } \\
\text { donau-mindel }\end{array}$ & moraine wurm & $\begin{array}{l}\text { polygenetic } \\
\text { moraine d-m }\end{array}$ \\
\hline community & & & & \\
\hline $\begin{array}{c}\text { structure } \\
\text { (before the } \\
\text { windthrow) }\end{array}$ & Lariceto-Picetum & Lariceto-Picetum & Lariceto-Picetum & Lariceto-Picetum \\
\hline $\begin{array}{l}\text { management } \\
\text { (after the } \\
\text { windthrow) }\end{array}$ & $\begin{array}{c}\text { comparative intact } \\
\text { forest }\end{array}$ & $\begin{array}{l}\text { extracted wood } \\
\text { mass }\end{array}$ & $\begin{array}{l}\text { non-extracted } \\
\text { wood mass }\end{array}$ & burnt forest \\
\hline $\mathrm{pH} \mathrm{H} \mathrm{H}_{2} \mathrm{O}(2005)$ & 4.2 & 4.3 & 3.9 & 4.8 \\
\hline $\mathrm{pH} \mathrm{H}_{2} \mathrm{O}(2016)$ & 3.7 & 3.9 & 4.4 & 4.0 \\
\hline$\%$ of $C_{\mathrm{ox}}(2005)$ & 6.4 & 4.8 & 7.6 & 4.2 \\
\hline$\%$ of $C_{\text {ox }}(2016)$ & 7.7 & 11.4 & 10.4 & 10.3 \\
\hline$\%$ of $N_{\text {tot }}(2005)$ & 0.7 & 0.5 & 0.7 & 0.6 \\
\hline$\%$ of $N_{\text {tot }}(2016)$ & 0.4 & 0.5 & 0.5 & 0.5 \\
\hline
\end{tabular}

Soil samples from all monitored localities were taken from the A horizon up to a depth of $15 \mathrm{~cm}$ from five sampling points during the vegetation period in 2005 and 2016. Soil from all five sampling points in each site was pooled to prepare the average soil sample. Under laboratory conditions, each of them was homogenized by quartering, sieved $(2 \mathrm{~mm})$ to fine soil and stored at $4{ }^{\circ} \mathrm{C}$ in darkness for approximately 10 days, until the soil samples were processed. The resulting fine soils were used for all chemical and microbiological analyses.

\subsection{Basic Chemical Analyses}

The aqueous $\mathrm{pH}$ was determined potentiometrically by means of a glass electrode in a 1:5 suspension of the sample substrate. Oxidizable organic carbon $\left(\% \mathrm{C}_{\mathrm{ox}}\right)$ content was determined by oxidimetry under laboratory conditions. Organic carbon is oxidized by oxygen released from $\mathrm{K}_{2} \mathrm{Cr}_{2} \mathrm{O}_{7}$ in a strong acidic moiety $\left(\mathrm{H}_{2} \mathrm{SO}_{4}\right)$. The amount of $\mathrm{O}_{2}$ that oxidized organic carbon is calculated using the difference between the non-reacted and reacted amounts of chromic acid $\left(\mathrm{K}_{2} \mathrm{Cr}_{2} \mathrm{O}_{7}\right.$ $+\mathrm{H}_{2} \mathrm{SO}_{4}$ ). The non-reacted chromic acid is detected by salt dilution titration. The total nitrogen amount $\left(\% \mathrm{~N}_{\text {tot }}\right)$ was determined according to Jodlbauer. Before distillation, organic nitrogen is converted into its ammonic form by catalytic mineralization with sulphuric acid. In concentrated $\mathrm{H}_{2} \mathrm{SO}_{4}$, phenol is nitrated into p-nitrophenol, subsequently reduced by hydrogen to p-aminophenol, and its amino-nitrogen is finally converted into the ammonic form. Ammoniacal nitrogen is detected by distillation [28].

Extractable basic nutrients ( $\mathrm{K}_{\mathrm{MII}}, \mathrm{Mg}_{\mathrm{MII}}, \mathrm{Ca}_{\mathrm{MII}}, \mathrm{K}_{\mathrm{MIII}}, \mathrm{Mg}_{\mathrm{MIII}}$, and $\mathrm{Ca}_{\mathrm{MIII}}$ ) were measured using ICP-AES VARIAN 725 ES atomic emission spectrometry with inductively coupled plasma in 2016 in the certificate laboratory of the National Forest Centre, Zvolen, Slovakia. Analyses of extractable basic nutrients were done in extraction solution according to Mehlich; analyses were done in the certificated laboratory. Analysis details: The chemical composition of MII and MIII extraction dilution is different. The MIII one is strong acidic ( $\mathrm{pH} 2$ ), recently used for forestal soils. It enables detection of microelements next to the macroelements. The second ones are undetectable by the MII method. Extraction dilution Mehlich's II: it is the acidic solution with $0.015 \mathrm{M} \mathrm{NH}_{4} \mathrm{~F}$ for higher solubility of different forms of phosphorus bound to $\mathrm{Fe}$ and $\mathrm{Al}$. There are also $0.2 \mathrm{M} \mathrm{NH}_{4} \mathrm{Cl}, 0.2 \mathrm{M}$ acetic acid, and $0.012 \mathrm{M} \mathrm{HCl}$ to desorb $\mathrm{K}, \mathrm{Ca}$, and $\mathrm{Mg}$ in the extraction solution. The solution must be prepared fresh daily as it is unstable over $24 \mathrm{~h}$. Extraction solution according to Mehlich III: there are the same 
chemicals present as in the Mehlich's II solution here, but its strong acidic reaction ( $\mathrm{pH}$ 2) is reached due to titration with $0.013 \mathrm{M} \mathrm{KNO}_{3}$. The solution models very well availability of soil nutrients to plants. Addition of EDTA $(0.001 \mathrm{M})$ enables release of nutritionally important microelements. The expiration time of the solution is $24 \mathrm{~h}$ as well [29].

\subsection{DNA Extraction and PCR Amplification}

The DNA from the samples REF, EXT, NEX, and FIR (recovered in 2016) was extracted by means of the DNeasy PowerSoil kit (Qiagen, Hilden, Germany) according to the manufacturer's instructions. The extracted DNA of the samples had a concentration which varied from 23 to $48 \mathrm{ng} / \mu \mathrm{L}$.

Three microliters of DNA from each sample were used for the amplification by various PCR assays oriented to the bacterial V1-V4 variable region of 16S rRNA gene (27f-AGA GTT TGA TCC TGG CTC AG/685r-TCT ACG CAT TTC ACC GCT AC) and fungal internal transcribed spacers (ITS; ITS1-TCC GTA GGT GAA CCT GCG G/ITS4-TCC TCC GCT TAT TGA TAT GC). The PCR conditions were as follows: $94{ }^{\circ} \mathrm{C} / 2 \mathrm{~min}$; 35 cycles: $94{ }^{\circ} \mathrm{C} / 1 \mathrm{~min} ; 54{ }^{\circ} \mathrm{C} / 1 \mathrm{~min} ; 72{ }^{\circ} \mathrm{C} / 1 \mathrm{~min} ; 72{ }^{\circ} \mathrm{C} / 8$ $\mathrm{min}$. The PCR mixtures $(25 \mu \mathrm{L})$ of each assay were comprised of the extracted DNA, 50 pmol of each primer, $200 \mu \mathrm{mol} / \mathrm{L}$ dNTP, $1 \mathrm{U}$ of Platinum Taq DNA polymerase (Thermo Fisher Scientific, Waltham, MA, USA), 1X PCR buffer and $1.5 \mathrm{mM} \mathrm{Mg}^{2+}$. Four microliters of each PCR amplicon were checked in $1 \%$ agarose gel and the rest of the PCR product was purified using a Monarch PCR cleanup kit (New England BioLabs, Ipswich, MA, USA). Ten microliters of sterile distilled water were used to elute the amplicon from the cleanup column. The purified product obtained from each PCR assay was analysed by high-throughput sequencing (HTS) using a MiSeq Illumina platform.

\subsection{High-Throughput Sequencing}

A sequence library was performed using the Nextera XT DNA library kit (Illumina, San Diego, CA, USA). Library preparation followed the standard library preparation protocol of the producer, with modifications. PCR was performed with 12 reaction cycles as recommended, but with $0.5 \mathrm{ng}$ of input DNA. Bacterial 16S rRNA and eukaryotic ITS amplicon sequences were tagmented by transposon to sequences of approximately $300 \mathrm{bp}$. Limited-cycle PCR and mutual indexing amplified the DNA library. Dual indexing enabled an increase in the number of pooled samples with a reduction of costs for high-throughput sequencing. Size selection was carried out with $45 \mathrm{~mL}$ AMPure XP beads to enrich the sample with fragments shorter than $500 \mathrm{bp}$. The libraries were validated using an Agilent 2100 Bioanalyzer (Agilent Technologies, Waldbronn, Germany) and the quantity was determined with a Qubit 2.0 Fluorometer (Thermo Fisher Scientific). For sequencing of the $4 \mathrm{nM}$ pool of libraries, a MiSeq Sequencing Kit v3 600 cycles (Illumina) was used. Paired-end sequencing was carried out with a 200 bp read length setting.

\subsection{Bioinformatic Evaluation}

We removed adapters and low quality ends of sequenced reads using Trimmomatic (parameters LEADING:20 SLIDINGWINDOW:5:20) [30] based on quality control statistics generated by FastQC [31]. After trimming, fragments without sufficient length of both reads (at least 35 bases) were removed from the read sets (Trimmomatic parameter MINLEN:35). We also filtered duplicated copies of DNA fragments, as they were most likely introduced by the PCR amplification [32].

Filtered reads from $16 \mathrm{~S}$ samples were labelled with taxonomy from the Silva database (version111) [33] using the Metaxa2 classifier [34]. ITS fragments were labelled using the Emirge classifier [35]. We used UNITE database version 7.1 [36] as the reference database of ITS gene sequences. We summarized the taxonomic counts in each sample and visualized them in the form of multilevel pie charts generated by KronaTools [37].

Taxonomic counts were compared with principal component analysis (PCA), performed with Python sklearn library [38]. Alpha diversities (Simpson metric) were calculated with the 
Python sklearn.diversity package [38]. Beta diversities (Bray Curtis metric) were calculated with in-house scripts.

\subsection{Isolation and Cultivation of Soil Filamentous Fungi Including Heat-Resistant Species}

The cultivable filamentous fungi were isolated by direct inoculation up to dilutions of $10^{4} \mathrm{CFU}$ (colony forming units) per $1 \mathrm{~g}$ of dry sample plates of CD (Czapek Dox agar), PDA (potato dextrose agar), MEA (malt extract agar) and SDA (Sabouraud dextrose agar; all HiMedia, Mumbai, India), followed by cultivation in the dark at $25^{\circ} \mathrm{C}$ for $7-10$ days. The heat-resistant fungal species were isolated from $100 \mathrm{~g}$ of fine-sieved soil heated in Rose Bengal $(150 \mathrm{mg} / \mathrm{L}$; HiMedia, Mumbai, India) enriched double strengthened SDA at $75^{\circ} \mathrm{C}$ for $30 \mathrm{~min}$, plated and subsequently cultivated at $25^{\circ} \mathrm{C}$ for 10-14 days according to Samson et al. [39]. All soil samples were processed in three replications. All of the morphologically distinct colonies were selected from the resulting mixed culture and purified. The isolates were then maintained on the original isolation agar media and identified up to the species level according to Pitt [40], de Hoog et al. [41], Samson and Frisvad [42] and Domsch et al. [43]. Molecular identification was applied in some cases as well, according to the ITS PCR protocol described in Section 2.3 and Sanger sequencing (outsourcing facility; Eurofins, Ebersberg, Germany). Valid fungal names were modified according to Hubka et al. [44] and Visagie et al. [45].

Beta diversity is the extent of differentiation of communities along habitat gradients [46]. In ecology, the similarity index is often used. The similarity of soil micromycocoenoses based on identified fungi was determined according to Sörensen $S_{S}=2 a /(2 a+b+c)$ and Jaccard $S_{J}=a /(a+b+c)$, where a is the number of species in sample $a, b$ is the number of species in sample $b$, and $c$ is the number of species common in both ( $\mathrm{a}$ and $\mathrm{b}$ ) samples [47].

\section{Results and Discussion}

\subsection{Soil Characteristics}

The plant community structure in all localities before the windthrow was characterized as Lariceto-Picetum. Lariceto-Piceetum, the larch-spruce forest, is the most common group of forest types in the central part of the Tatra National Park. It grows on an area of almost 4500 ha, vertically, from an elevation of about $1000 \mathrm{~m}$ up to the high forestal border. Acidophilic species of the herbal level, such as Vaccinium myrtillus, Oxalis acetosella, Rubus hirtus, Prenanthes purpurea, Polygonatum verticillatum, Dryopteris dillatata, and Athyrium filix-femina, are typical or may even dominate in this forest [18].

Dystric Cambisol is the type of soil in the area studied [48]. Cambisols are the most widespread soil types in Slovakia, with increased raw humus content in climatically steep altitudes, as is typical for the Tatra Mountains. At all locations, the values of soil pH ranged from pH 3.9 to $\mathrm{pH} 4.8$ in 2005, and from $\mathrm{pH} 3.7$ to $\mathrm{pH} 4.4$ in 2016. Despite the fact that, throughout eleven years the $\mathrm{pH}$ values have fallen, they remain significantly acidic regardless of the chosen management at localities after the windthrow. We detected an increase of $\% \mathrm{C}_{\mathrm{ox}}$ at all plots in 2016 compared to 2005 (REF 1.20x; EXT 3.37x; NEX 1.39x; FIR 2.45x). This corresponds to the findings of Fleischer and Homolová [17]. Extracted (EXT) and burnt (FIR) plots showed more significant increases compared to plots with intact forest (REF) and those with non-extracted wood mass (NEX), which was caused by wood extraction at the plot EXT and by fire ash at the plot FIR. Wood extraction allowed rapid secondary succession of the herbal layer, enhancing primary production and, thus, carbon content in topsoil. A similar effect was observed at the plot FIR, where the extracted area, fertilized by ashes from the fire, enhanced primary production and nutrient availability. Measurements of $\% \mathrm{~N}_{\text {tot }}$ in 2016 indicated a decrease compared to 2005 at the plot REF by $1.94 \times$, NEX $1.27 \times$ and FIR $1.09 \times$, while at EXT, the $\% \mathrm{~N}_{\text {tot }}$ increased by $1.08 \times$. As presented in Table 1, there are differences between the FIR locality and the others. The effects of fire and the application of wood ash to forest soils are used to compensate nutrient loss and avoid water acidification [49-51]. According to Bogunovic et al. [52], Heydari et al. [53], and Xue et al. [54], fire modifies concentrations of extractable basic nutrients such as potassium $(\mathrm{K})$, magnesium $(\mathrm{Mg})$, 
and calcium (Ca). Despite the fact that analyses of extractable basic nutrients were done only in 2016, there is a clear difference between the studied locations, with the maximum values detected at the burnt locality (Table 2). Thermal ash analysis made in 2005 from the FIR locality showed that the samples contained about $7 \mathrm{wt} \%$ of water and light pyrolysis products. The TG analysis measurements were taken using STD 2960 (T.A. Instruments, Artisan technology group, Champaign, IL, USA) in linear heating regimes with the rates $5.0^{\circ} \mathrm{C} \mathrm{min}-1$ in temperature region $30.0-800.0{ }^{\circ} \mathrm{C}$. An organic fraction of approximately $50 \mathrm{wt} \%$ is released at temperatures below $600^{\circ} \mathrm{C}$. Above this temperature, the change in the ash mass is only $1 \mathrm{wt} \%$. This means that the inorganic fraction of carbon is low and that the ash samples are the product of incomplete combustion $[55,56]$. At this location, a $3 \mathrm{~cm}$ thick layer of burnt organic material is visible (Figure 3).

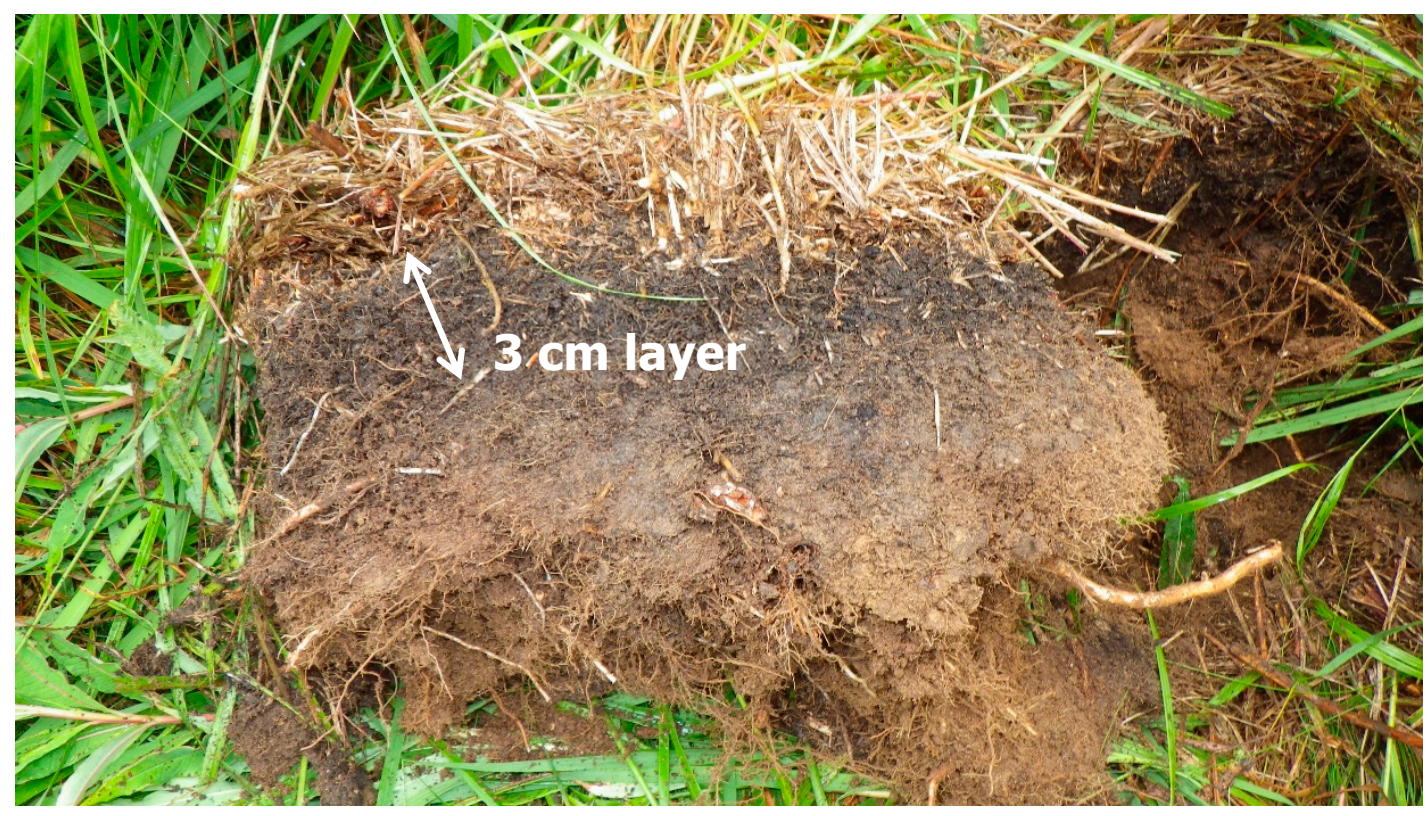

Figure 3. Sample from FIR locality with $3 \mathrm{~cm}$ thick visible layer of burnt organic material (Photo: A. Šimonovičová).

Table 2. Extractable basic nutrients at monitored localities in the High Tatra Mountains in 2016.

\begin{tabular}{ccccc}
\hline \multirow{2}{*}{ Basic Nutrients } & \multicolumn{4}{c}{ Monitored Localities } \\
\cline { 2 - 5 } & REF & EXT & NEX & FIR \\
\hline $\mathrm{K}_{\text {MII }} \mathrm{mg} / \mathrm{kg}$ & 88.1 & 106 & 94.1 & 132 \\
$\mathrm{Mg}_{\mathrm{MII}} \mathrm{mg} / \mathrm{kg}$ & 26.5 & 79 & 47 & 104 \\
$\mathrm{Ca}_{\text {MII } \mathrm{mg} / \mathrm{kg}}$ & 103 & 461 & 320 & 820 \\
$\mathrm{~K}_{\text {MIII } \mathrm{mg} / \mathrm{kg}}$ & 150 & 156 & 147 & 183 \\
$\mathrm{Mg}_{\text {MIII } \mathrm{mg} / \mathrm{kg}}$ & 27.9 & 77.7 & 44.8 & 98.2 \\
$\mathrm{Ca}_{\text {MIII }} \mathrm{mg} / \mathrm{kg}$ & 103 & 458 & 310 & 801 \\
\hline
\end{tabular}

\subsection{High-Throughput Sequencing Analysis of Bacterial $16 S$ rRNA Gene}

High-throughput amplicon sequencing analysis of the soil microbiome, oriented to the 16S rRNA gene, revealed certain differences among the analysed soil samples. Percentages were calculated from the number of identified reads, which were assigned to the given taxa based on homology to reference sequences in the Silva database.

The analysed reads were divided into four major phyla: Proteobacteria $(56.07 \%$ NEX; $23.94 \%$ FIR; $43.10 \%$ EXT; $67.83 \%$ REF), Actinobacteria $(16.10 \% ; 48.52 \% ; 25.91 \% ; 9.01 \%)$, Verrucomicrobia $(5.53 \%$; $2.95 \% ; 4.76 \% ; 7.60 \%)$, and Bacteroidetes $(1.48 \% ; 5.31 \% ; 4.78 \% ; 1.04 \%)$. The abundance of sequence reads 
assigned to the given taxa at the genera level is graphically summarized in Figure 4 for those detected in quantities above $0.5 \%$.

The uncultured genus Desulfurellaceae H16 (13.93\%; 3.38\%; 12.26\%; 19.63\%) belonging to the Desulfurellaceae family were the most commonly detected, followed by the genera Acidothermus $(6.43 \%$; $17.64 \% ; 12.67 \% ; 5.09 \%$ ), Acidibacter (Xanthomonadales Incertae Sedis; $11.83 \% ; 5.57 \% ; 7.29 \% ; 14.83 \%$ ), Mycobacterium (3.51\%; 17.94\%; 6.99\%; 2.31\%), and Burkholderia-Paraburkholderia $(6.91 \% ; 2.89 \% ; 5.13 \%$; $3.87 \%)$.

Nevskia $(0.74 \% ; 1.60 \% ; 0.55 \% ; 14.01 \%)$, Opitutus $(3.79 \% ; 1.62 \% ; 3.11 \% ; 5.77 \%)$, Rhodanobacter $(7.27 \%$; $0.80 \% ; 5.51 \% ; 0.50 \%)$, Nocardia $(2.44 \% ; 5.53 \% ; 3.30 \% ; 1.08 \%)$, and Pseudomonas $(4.36 \% ; 2.91 \% ; 1.38 \%$; $2.31 \%$ ) were also within the top 10 bacterial genera detected.

The genus Acidothermus occurred more on the locality FIR (17.64\%) and on the locality EXT (12.67\%). Acidothermus cellulolyticus is the sole species, in the sole genus of the family Acidothermaceae [57]. A. cellulolyticus was described by Mohagheghi et al. [58] as a thermophilic, acidophilic, and cellulolytic bacterium, capable of rapid degradation of cellulose and with relatively high growth temperatures. It was isolated from Yellowstone National Park, Wyoming, USA. Barabote et al. [59] presented the complete genome of A. cellulolyticus. A sizable fraction of its hydrolytic enzymes break down plant cell walls, while the remaining ones either degrade components of fungal cell walls or metabolize storage carbohydrates such as glycogen and trehalose, implying the relative importance of these different sources. These abilities also elevate the industrial value of the species.

Mycobacteria were the predominant taxa in the organic soil horizons in the New Jersey Pinelands after a severe wildfire which burned over 7000 ha [60]. Due to their cell wall composition and their adaptability, they can survive in different habitats. The environmental diversity of fast-growing mycobacteria remains largely unknown. However, they could be of major interest for bioremediation of PAH-contaminated soils [61]. The amount of Mycobacterium spp. was relatively low in our soil samples, except at the locality FIR (17.94\%).

Nocardia, Nocardioides, and Streptomyces belonging to the phylum Actinobacteria were predominant in the FIR locality (5.53\%). This finding is in agreement with other investigations, which described a higher presence of Actinobacteria in soils after wildfire [62-64].

The prevalence of the members of the genus Nevskia was shown only in the soil sample from the REF locality (14.01\%). The members of the genus Nevskia are isolated relatively rarely from soils and are very sensitive to soil $\mathrm{pH}$, organic carbon, and organic nitrogen [65]. Most of Nerskia spp., e.g., N. ramosa [66], N. aquatilis and N. persephonica [67], inhabit aqueous environments, while N. soli [68] and N. terrae [69] are isolated mainly from soils.

The presence of denitrifying bacteria from the genus Rhodanobacter is correlated to lower $\mathrm{pH}$ conditions. These bacteria are abundant and active mostly in areas highly contaminated by uranium and nitrate [70]. In our study, Rhodanobacter reads were observed mostly in two localities, NEX (7.27\%) and EXT (5.51\%) (Figure 4). 


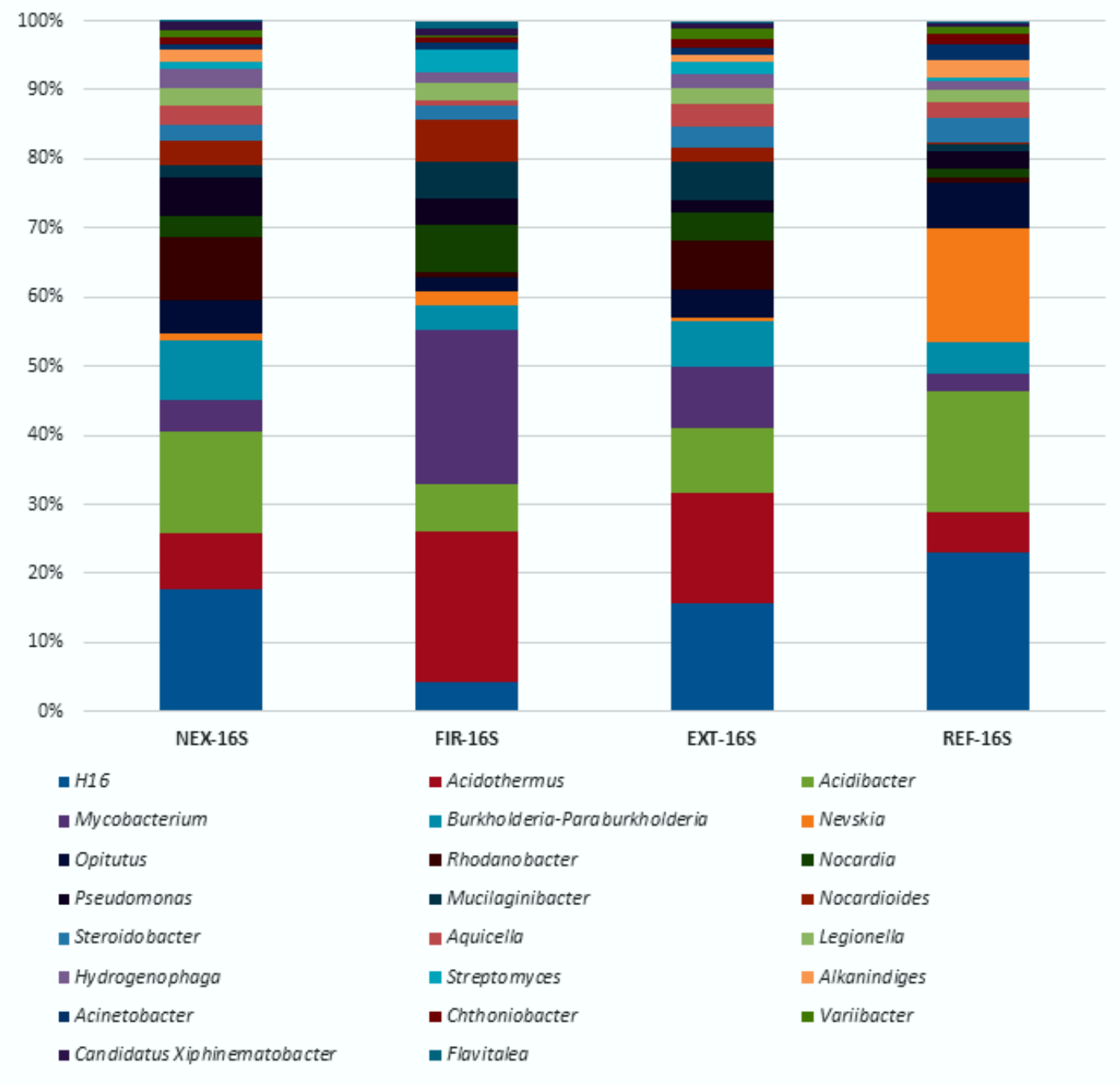

Figure 4. Percentage of $16 \mathrm{~S}$ rRNA gene-encoded sequence reads assigned to the given bacterial genera detected in individual samples (NEX, FIR, EXT, and REF).

\subsection{High-Throughput Sequencing Analysis of Fungal ITS Fragment}

The most abundant genera detected in all four localities are graphically summarized in Figure 5. The major phyla detected by sequencing were comprised of Ascomycota $(23.11 \%$ NEX; $20.59 \%$ FIR; $27.98 \%$ EXT; $23.60 \%$ REF), Basidiomycota (30.53\%; 7.86\%; 10.49\%; 3.11\%), Mortierellomycota $(3.00 \%$; $5.27 \% ; 2.92 \% ; 4.09 \%)$, Mucoromycota $(0.06 \% ; 1.29 \% ; 0.25 \% ; 0.89 \%)$ and Zoopagomycota $(0.19 \% ; 0.08 \%$; $0.61 \% ; 0.00 \%)$. These five phyla were further represented by 12 classes: Agaricomycetes $(23.80 \%$; $6.99 \% ; 10.08 \% ; 2.82 \%)$, Archaeorhizomycetes $(1.25 \% ; 13.87 \% ; 12.47 \% ; 12.50 \%)$, Leotiomycetes $(13.84 \%$; $5.14 \% ; 8.74 \% ; 8.25 \%)$, Mortierellomycetes $(3.00 \% ; 5.27 \% ; 2.92 \% ; 4.09 \%)$, Eurotiomycetes $(1.27 \% ; 0.60 \%$; $4.41 \% ; 1.42 \%)$, Microbotryomycetes $(6.62 \% ; 0.05 \% ; 0.11 \% ; 0.15 \%)$, Saccharomycetes $(5.47 \% ; 0.00 \% ; 0.00 \%$; $0.00 \%)$, Dothideomycetes $(1.28 \% ; 0.98 \% ; 1.50 \% ; 1.42 \%)$, Umbelopsidomycetes $(0.06 \% ; 1.29 \% ; 0.25 \%$; $0.89 \%)$, Tremellomycetes $(0.11 \% ; 0.82 \% ; 0.30 \% ; 0.14 \%)$, Sordariomycetes $(0.00 \% ; 0.00 \% ; 0.87 \% ; 0.00 \%)$, and Zoopagomycetes $(0.19 \% ; 0.08 \% ; 0.61 \% ; 0.00 \%)$; and 16 orders: Archaeorhizomycetales $(1.25 \% ; 13.87 \%$, $12.47 \%, 12.50 \%)$, Agaricales $(2.20 \% ; 3.00 \% ; 1.00 \% ; 0.00 \%)$, Atheliales $(5.63 \% ; 0.03 \% ; 0.60 \% ; 0.95 \%)$, Boletales $(0.83 \% ; 1.87 \% ; 0.98 \% ; 0.57 \%)$, Capnodiales $(1.28 \% ; 0.98 \% ; 1.50 \% ; 1.42 \%)$, Eurotiales $(1.27 \% ; 0.60 \% ; 4.41 \%$; $1.42 \%)$, Helotiales (13.84\%; $5.14 \% ; 8.74 \% ; 8.25 \%)$, Hypocreales $(0.00 \% ; 0.00 \% ; 0.87 \% ; 0.00 \%)$, Mortierellales $(3.00 \% ; 5.27 \% ; 2.92 \% ; 4.09 \%)$, Russulales $(14.79 \% ; 0.09 \% ; 4.61 \% ; 1.30 \%)$, Saccharomycetales $(5.47 \% ; 0.00 \%$; $0.00 \% ; 0.00 \%)$, Sporidiobolales $(6.62 \% ; 0.05 \% ; 0.11 \% ; 0.15 \%)$, Thelephorales $(0.36 \% ; 1.99 \% ; 2.89 \% ; 0.00 \%)$, 
Tremellales $(0.11 \% ; 0.82 \% ; 0.30 \% ; 0.14 \%)$, Umbelopsidales $(0.06 \% ; 1.29 \% ; 0.25 \% ; 0.89 \%)$, and Zoopagales $(0.19 \% ; 0.08 \% ; 0.61 \% ; 0.00 \%)$.

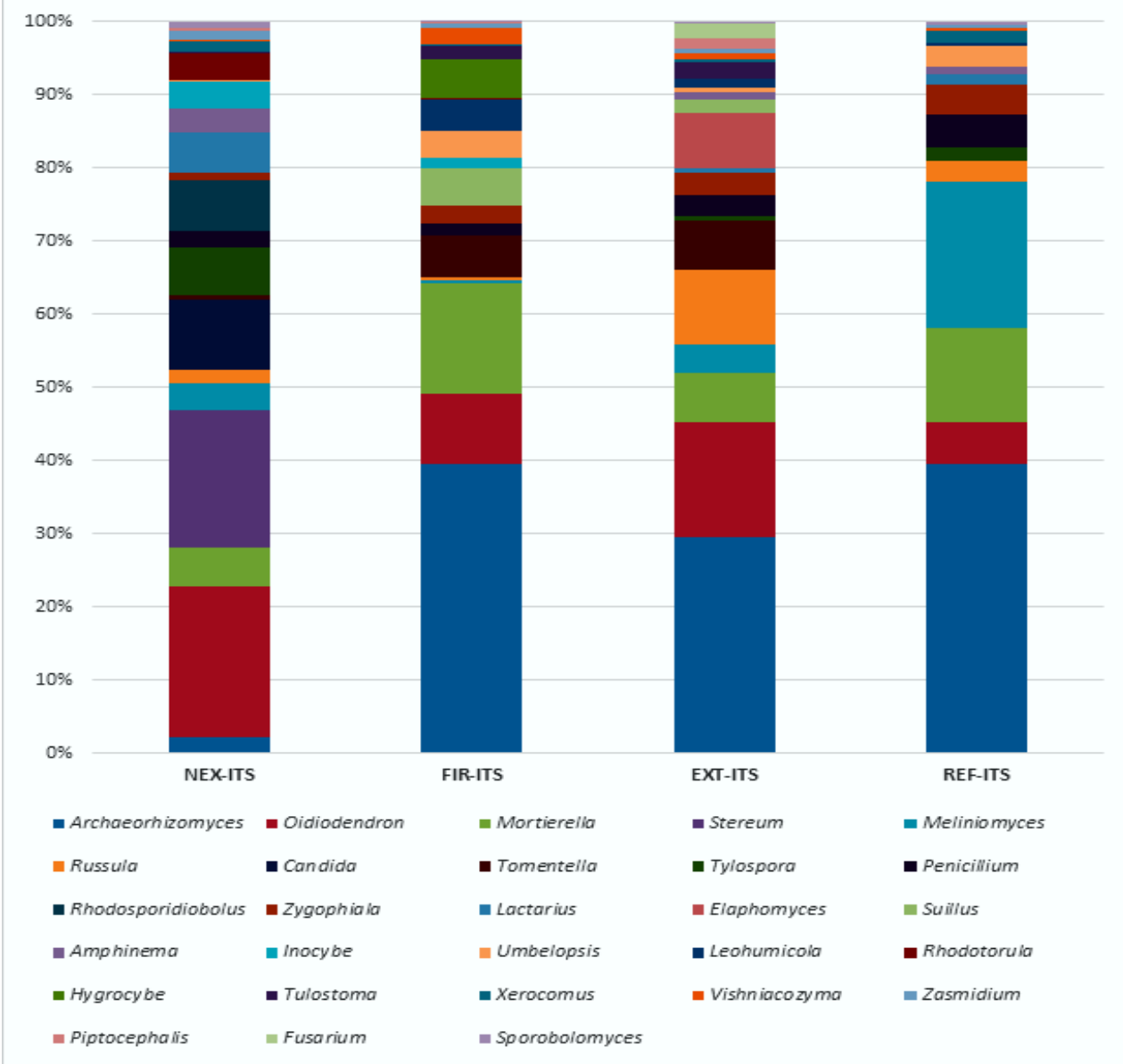

Figure 5. Percentage of ITS sequence reads assigned to the given fungal genera detected in individual samples (NEX, FIR, EXT, and REF).

\subsubsection{The Most Abundant Fungal Taxa in All Investigated Samples}

Despite the fact that the taxa of Archaeorhizomyces are considered to be ubiquitous and are detected in many soil ecosystems worldwide [71], our study revealed their relatively low abundance $(1.25 \%)$ in the NEX locality (with non-extracted wood mass after the windthrow left for self-regeneration). Their highest quantity (13.87\%) was found at the FIR locality (which suffered a fire in the year 2005). Choma et al. [72] stated that the low abundance of Archaeorhizomycetes in the soil fungal communities might be non-negligible.

Oidiodendron (11.75\%) was the most common detected taxa in the NEX locality. The genus Oidiodendron, also known as cosmopolitan fungi, is usually found in soil or different cellulose substrates [43]. Mortierella spp. are typical moulds in soil and rhizospheres, including those of conifers [73] and are commonly considered as soil-inhabiting saprobic organisms in decaying organic matter [74]. The study of Štursová et al. [75] revealed that the presence of saprotrophic Mortierella and Meliniomyces, mycorrhizal symbionts of bilberries, in soil samples during bark beetle-induced tree dieback was steady over time, but variable. The distribution of reads identified as Mortiella was, in our case, approximately equal among the investigated localities (NEX, FIR, EXT, REF), with a slight predominance in the FIR locality. The genus Meliniomyces (6.32\%) was significant in the REF locality (intact forest ecosystem). 


\subsubsection{The Significant Abundance of Fungal Taxa on the NEX Locality}

Genera of Stereum (10.61\%), Candida (5.47\%), and Rhodosporidiobolus (3.96\%) were observed only in the NEX locality (non-extracted wood mass after the windthrow left for self-regeneration) soil with relatively high abundance. Representatives of the Stereum spp. are known for their wood decay capabilities [76]; therefore, it is not surprising that this genus was only observed there. An earlier study by González et al. [77] revealed numerous new yeasts belonging to Candida species present in decayed wood material, detected mainly in the initial stages of delignification and fungal transformation in cattle feed. Many species of this genus were subsequently described and isolated from decayed wood material, e.g., Candida santjacobensis and C. ancudensis [78].

Not all yeast species isolated from soils are indigenous soil inhabitants, as they may originate from other sources. Yeasts from plant surfaces, e.g., Rhodotorula, Rhodosporidiobolus, and Sporobolomyces, are often recovered from soils [79]. Thus, only Rhodosporidiobolus $(3.96 \%$ NEX; 0.00\% FIR; 0.00\% EXT; $0.00 \%$ REF), Rhodotorula $(2.16 \% ; 0.02 \% ; 0.00 \% ; 0.00 \%)$, and Sporobolomyces $(0.50 \% ; 0.02 \% ; 0.11 \% ; 0.15 \%)$ were present, predominantly in the NEX locality.

Other genera, such as Tylospora $(3.69 \% ; 0.03 \% ; 0.25 \% ; 0.58 \%)$, Lactarius $(3.12 \% ; 0.00 \% ; 0.29 \%$; $0.41 \%)$, Amphinema (1.93\%; 0.00\%; 0.35\%; 0.36\%), Inocybe (2.07\%; $0.45 \% ; 0.04 \% ; 0.00 \%)$, and Zasmidium $(0.69 \% ; 0.19 \% ; 0.26 \% ; 0.09 \%)$, also prevailed in the NEX locality in comparison to the other localities. The genera of ectomycorrhizal fungi, such as Tylospora and Lactarius, were mainly identified in spruce or oak soil plots in a previous study [80]. Amphinema spp. was also detected and identified as one of the dominant taxa in the forest soil samples after clear-cut logging [81].

\subsubsection{The Significant Abundance of Fungal Taxa on the FIR Locality}

The genus Hygrocybe was observed (1.90\%) only in the FIR locality (fire in 2005), and the abundance of the genus Umbelopsis $(0.06 \% ; 1.29 \% ; 0.25 \% ; 0.89 \%)$ was higher in this locality when compared with the others. Although the genus Hygrocybe was one of the five most abundant genera (3.7\%) in soil microbial communities from the northern coniferous forests after timber harvesting [82], in our case this genus was absent in all localities except for FIR (1.9\%). Štursová et al. [83] demonstrated the presence of the genus Hygrocybe in Picea abies forest litter microcosmos. Also, the genus Umbelopsis was described as a fresh litter inhabitant with its seasonal maximum in autumn [84]. Some discrepancies with the published data by Azaz and Pekel [85] were observed in the case of the genus Penicillium. These authors described this genus as the richest taxa occurring in burnt forest soils, analysed by a cultivation soil dilution plate method. In our case, these genera had the lowest abundance $(0.6 \%)$ in the FIR locality, approximately two times lower than in the other localities. Similar data were obtained by Widden and Parkinson [86]. They concluded that the species of Penicillium were devitalized by the heat of the fire and were subsequently unable to recolonize the upper layers of the soil. In addition, the genus Amphinema was missing in the FIR locality.

\subsubsection{The Significant Abundance of Fungal Taxa on the EXT and REF Localities}

The genus Russula (4.33\%) appeared to be significant in the EXT locality (extracted wood mass after the windthrow), while the genera of Elaphomyces (3.20\%) and Fusarium (0.87\%) were only observed in this location. Tomentella $(2.89 \%)$ was observed mostly in the EXT area and was absent in the REF locality.

The ectomycorrhizal mushrooms belonging to the genus Russula, together with Lactarius, are members of the family Russulaceae, which are among the most speciose and abundant groups of boreal ectomycorrhiza (ECMR) [87]. Štursová et al. [75] observed the relatively high abundance of Russula in the forest soil after 2 years of tree dieback, which may be associated with its potential ability to grow saprotrophically and to decompose the structural polymers of dead spruce roots [83]. The presence of Russula was approximately 4 times higher in the EXT locality than in the other three analysed samples, reaching a percentage of $4.33 \%$. Vořišková et al. [84] demonstrated that the abundance of ECMR in the temperate oak forest soil varies during the seasons. The results of their work 
revealed that the highest abundances of Russula (7\%), Lactarius (6\%), and Tomentella (not quantified) were recorded in summer, and the lowest ones (Russula $1 \%$ and Lactarius $0.3 \%$ ) in spring. Fusarium is important as a biodegradation agent, surviving from one season to the next on decaying plant material, and is able to survive for up to 16 years in the soil [88].

Despite the fact that the taxa of Archaeorhizomyces are considered to be ubiquitous and are detected in many soil ecosystems worldwide [71], our study revealed its relatively low abundance $(1.25 \%)$ in the NEX locality (non-extracted wood mass after the windthrow left for self-regeneration) and the highest (13.87\%) in the FIR locality (fire in 2005). Choma et al. [72] described that the low abundance of Archaeorhizomycetes in soil fungal communities might be non-negligible.

Oidiodendron (11.75\%) was the most-often-detected taxon in the NEX locality. Oidiodendron is known as a cosmopolitan taxon whose members are usually found in soil or on different cellulose substrates [43]. Mortierella spp. are typical in soil and rhizospheres, including those of conifers [73] and its members are commonly considered to be soil-inhabiting saprobic organisms on decaying organic matter [74]. The study by Štursová et al. [75] revealed that the presence of saprotrophic Mortierella and Meliniomyces, mycorrhizal symbionts of bilberries, in soil samples during bark beetle-induced tree dieback, was steady over time but variable. The distribution of reads found that Mortiella was, in our case, approximately equal among the investigated localities (NEX, FIR, EXT, REF), with a slight predominance in the FIR locality.

Only the genus Meliniomyces (6.32\%) was significant at the REF locality (intact forest ecosystem).

\subsection{Alpha and Beta Diversity Analysis}

The results of alpha and beta diversity analysis are summarized in Table 3 and Figure 6, respectively. According to these results, the highest alpha diversity, in the case of bacteria calculated from all taxa detected on the genus degree, was observed in the sample EXT (0.945), and the lowest in the sample REF (0.907). The highest alpha diversity in the case of fungi was observed in the sample NEX (0.946), and the lowest in the sample REF (0.905). Beta diversity analysis showed that the bacterial communities differed mostly between samples REF and FIR (0.594), and the lowest bacterial diversity was observed between samples NEX and EXT (0.224). The highest fungal beta diversity occurred between REF and EXT localities (0.752), and the most similar fungal consortia composition was between samples from locality REF and EXT (0.364).

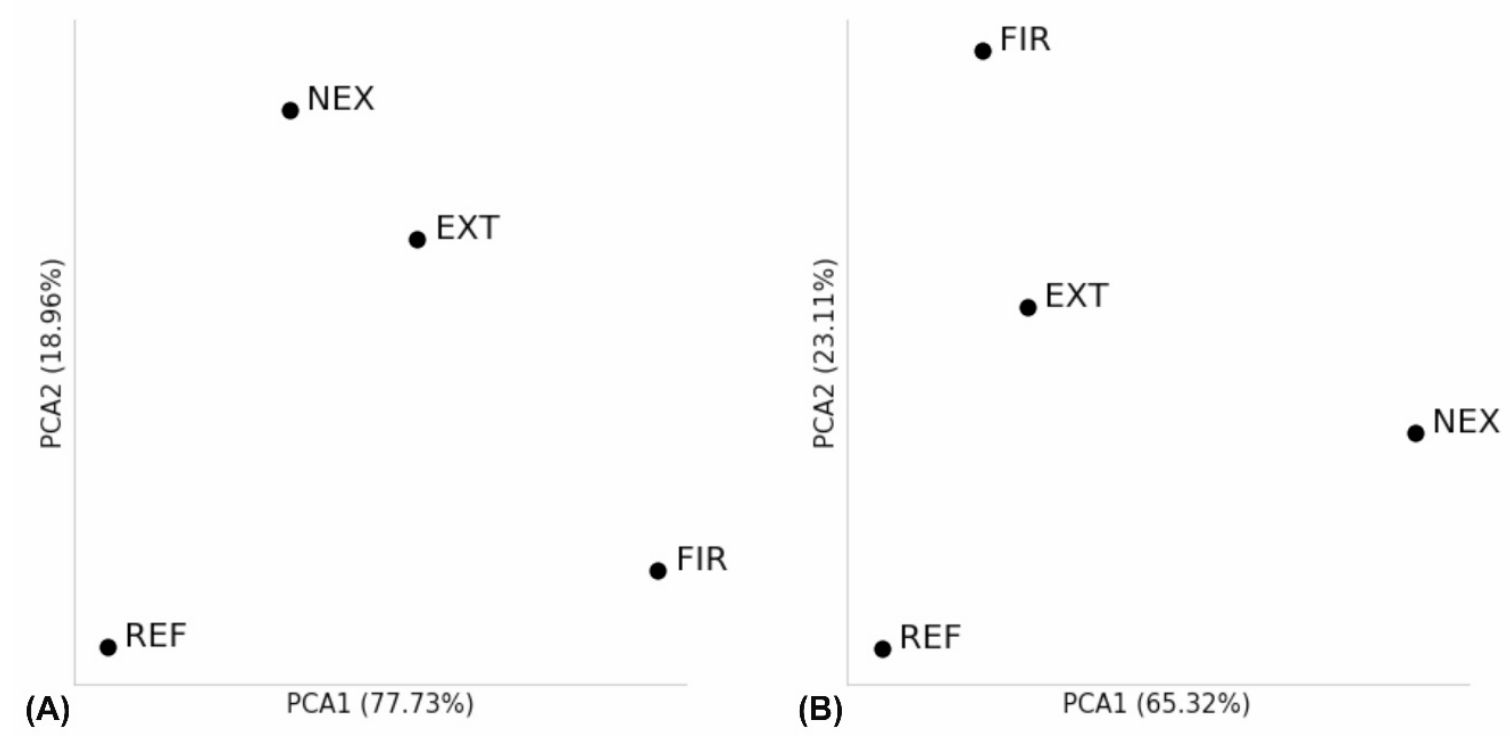

Figure 6. Principal component analysis of bacterial (A) and fungal (B) microbial compositions. Distance between analysed taxonomic counts, represented by points, corresponds to similarity of their compositions. 
Table 3. Alpha diversity analysis of microbial consortia of the localities EXT, FIR, NEX, and REF. The highest values referring to highest diversity are underlined. The lowest values referring to lowest diversity are in bold.

\begin{tabular}{ccccc}
\hline Alpha Diversity Analysis & EXT & FIR & NEX & REF \\
\hline 16S bacteria (genus degree) & $\underline{0.945}$ & 0.920 & 0.943 & $\mathbf{0 . 9 0 7}$ \\
\hline ITS fungi (genus degree) & 0.944 & 0.934 & $\underline{0.946}$ & $\mathbf{0 . 9 0 5}$ \\
\hline
\end{tabular}

\subsection{Cultivable Soil Filamentous Fungi}

Thirty-two genera and 58 species of soil filamentous fungi were recovered from the Dystric Cambisol soil samples. In 2005, the diversity of soil filamentous fungi was relatively low in all of the studied samples (12 species at the localities REF and NEX, 15 species at FIR, and 17 at EXT). In 2016, a slight increase in biodiversity was recorded, starting with the locality NEX (19 species), and increasingly more pronounced in the REF (22 species), EXT (27 species), and FIR (28 species) locations. At all of the localities tested, Zygomycota occurred relatively rarely, and Mortierella bainieri, Mucor hiemalis $\mathrm{f}$. hiemalis, Zygorhynchus heterogamus, and Z. moelleri were their most abundant representatives. Ascomycota dominated in all of the localities, of which Penicillium was the most abundant genus (22 species). The localities EXT, REF, and NEX showed minimal mycological differences. Aspergillus thermomutans as Neosartorya pseudofischeri, Chaetomium sp., Ch. atrobrunneum, Ch. funicola, Lasiodiplodia theobromae, Penicillium alutaceum as Eupenicillium alutaceum, P. expansum, P. funiculosum, P. inusitatum as E. inusitatum, P. indonesiae as E. ludwigii, P. melanoforme as E. melanoforme, P. osmophilum as E. osmophilum, P. parvum as E. parvum, Phialophora bubakii, Scopulariopsis sp., Staphylotrichum coccosporum, Talaromyces wortmanii, and Dichobotrys abundans were isolated only from the burnt locality (FIR). Most of these were isolated after heat treatment of the soil samples (Table 4).

Table 4. Soil filamentous fungi at monitored localities in the High Tatra Mountains in 2005/2016.

\begin{tabular}{|c|c|c|c|c|}
\hline \multirow{2}{*}{ Genera/Species/Sequence Similarity } & \multicolumn{4}{|c|}{ Localities } \\
\hline & REF & EXT & NEX & FIR \\
\hline Absidia sp. & $-1-$ & $+/+$ & $-1-$ & $-1-$ \\
\hline Achaetomium sp. & $-1-$ & $-1-$ & $+/+$ & $+/+$ \\
\hline Acremonium murorum & $-1-$ & $+/+$ & $-1-$ & $-1-$ \\
\hline Alternaria alternata & $+/+$ & $+/+$ & $-1-$ & $+/+$ \\
\hline Aspergillus fischeri & $+/-$ & $+/-$ & $+/-$ & $+/-$ \\
\hline Aspergillus fischeri as * Neosartorya fischeri & + & + & - & + \\
\hline Aspergillus fischeri var. glaber as EF669938 * Neosartorya glabra $100 \%$ & $-1+$ & $-1+$ & $-1-$ & $-/+$ \\
\hline Aspergillus thermomutatus as Neosartorya pseudofischeri & $-1-$ & $-1-$ & $-1-$ & $-/+$ \\
\hline Botryotrichum piluliferum & $-1-$ & $-1-$ & $+/+$ & $-1-$ \\
\hline FJ527879 Chaetomium sp. $99.8 \%$ & $-1-$ & $-1-$ & $-1-$ & $-/+$ \\
\hline * Chaetomium atrobrunneum & $-1-$ & $-1-$ & $-1-$ & $-/+$ \\
\hline Chaetomium funicola & $-1-$ & $-1-$ & $-1-$ & $-/+$ \\
\hline JN601442 Cladosporium 100\% & $+/+$ & $-1-$ & $+/+$ & $-1-$ \\
\hline LN834375 Cladosporium halotolerans 100\% & $-1-$ & $-1-$ & $-1+$ & $-1-$ \\
\hline KC113297 Cladosporium sphaeospermum $100 \%$ & $-1+$ & $-/+$ & $-1+$ & $-1-$ \\
\hline Clonostachys rosea f. rosea & $-1-$ & $-1+$ & $-1-$ & $-1-$ \\
\hline Dichobotrys abundans as DQ220449 Trichophaea abundans 100\% & $-1-$ & $-1-$ & $-1-$ & $-/+$ \\
\hline${ }^{*}$ Eupenicillium pinetorum & $-1-$ & $-1-$ & $-1+$ & $-1-$ \\
\hline AF033389 Geosmithia argillacea $92 \%$ & $-1+$ & $-1-$ & $-1-$ & $-1-$ \\
\hline Gliocladium sp. & $-1-$ & $-1-$ & $+/+$ & $-1-$ \\
\hline
\end{tabular}


Table 4. Cont

\begin{tabular}{|c|c|c|c|c|}
\hline \multirow{2}{*}{ Genera/Species/Sequence Similarity } & \multicolumn{4}{|c|}{ Localities } \\
\hline & REF & EXT & NEX & FIR \\
\hline LC076682 Hamigera striata 100\% & $-/+$ & $-/+$ & $-/+$ & $-1+$ \\
\hline * Lasiodipodia theobromae & $-1-$ & $-1-$ & $-1-$ & $-/+$ \\
\hline Lecanicillium muscarium & $-1-$ & $-/+$ & $-1-$ & $-1-$ \\
\hline Mortierella alpina & $-1-$ & $-/+$ & $-1-$ & $-1-$ \\
\hline Mortierella bainieri & $+/+$ & $+/+$ & $+/+$ & $-1-$ \\
\hline Mucor sp. & $+/+$ & $-1-$ & $+/+$ & $+/+$ \\
\hline Mucor hiemalis $\mathrm{f}$. hiemalis & $-1+$ & $-1+$ & $-1+$ & $-1-$ \\
\hline Myceliophtora thermophila & $-1-$ & $+/+$ & $+/+$ & $-1-$ \\
\hline${ }^{*}$ Myxotrichum deflexum & $-/+$ & $-1-$ & $-1-$ & $-1-$ \\
\hline Paecilomyces sp. & $+/+$ & $-1-$ & $-1-$ & $+/+$ \\
\hline Penicillium sp. & $+/+$ & $+/+$ & $+/+$ & $+/+$ \\
\hline Penicillium abidjanum as * Eupenicillium abidjanum & $+/+$ & $-/-$ & $+/+$ & $+/+$ \\
\hline Penicillium alutaceum as * Eupenicillium alutaceum & $-1-$ & $-1-$ & $-/+$ & $-/+$ \\
\hline Penicillium baarnense as * Eupenicillium baarnense & $-1-$ & $-1+$ & $-1-$ & $-1-$ \\
\hline Penicillium brefeldianum as * Eupenicillium brefeldianum & $-1-$ & $-/+$ & $-1-$ & $-1-$ \\
\hline KT200263 Penicillium chrysogenum var. chrasogenum $100 \%$ & $-1+$ & $-/+$ & $-1+$ & $-1-$ \\
\hline Penicillium expansum & $-1-$ & $-1-$ & $-1-$ & $+/-$ \\
\hline Penicillium funiculosum & $-1-$ & $-1-$ & $-1-$ & $-/+$ \\
\hline DQ682590 Penicillium glabrum $99.8 \%$ & $-1-$ & $+/+$ & $+/+$ & $+/+$ \\
\hline Penicillium inusitatum as * Eupenicillium inusitatum & $-1-$ & $-1-$ & $-1-$ & $-/+$ \\
\hline Penicillium indonesiae as * Eupenicillium erubescens & $-1-$ & $-/+$ & $-1-$ & $-1-$ \\
\hline Penicillium indonesiae as * Eupenicillium ludwigii & $-1-$ & $-1-$ & $-1-$ & $-/+$ \\
\hline * Penicillium janthinellum & $-1-$ & $+/+$ & $-1-$ & $-1-$ \\
\hline Penicillium lapidosum as * Eupenicillium lapidosum & $+/+$ & $-1-$ & $-1-$ & $+/+$ \\
\hline Penicillium melaforme as * Eupenicillium melaforme & $-1-$ & $-1-$ & $-1-$ & $-/+$ \\
\hline Penicillium osmophilum as * Eupenicillium osmophilum & $-1-$ & $-1-$ & $-1-$ & $-/+$ \\
\hline KM871190 Penicillium oxalicum 100\% & $-1+$ & $-1-$ & $-1-$ & $-1-$ \\
\hline Penicillium parvum as * Eupenicillium parvum & $-1-$ & $-1-$ & $-1-$ & $-/+$ \\
\hline Penicillium raistrickii & $-1-$ & $+/+$ & $-1-$ & $-1-$ \\
\hline * Penicillium sclerotigenum & $-1-$ & $-/+$ & $-1+$ & $-1-$ \\
\hline *Phialophora bubakii & $-1-$ & $-1-$ & $-1-$ & $-/+$ \\
\hline *Phoma sp. & $-1-$ & $-/+$ & $-1-$ & $-1-$ \\
\hline Rhizopus stolonifer var. stolonifer & $+/+$ & $-1-$ & $-1-$ & $-1-$ \\
\hline Scopulariopsis sp. & $-1-$ & $-/-$ & $-1-$ & $-1+$ \\
\hline * Scopulariopsis asperula & $-1+$ & $-1-$ & $-1-$ & $-1-$ \\
\hline * Staphylotricum coccosporum & $-/-$ & $-/-$ & $-1-$ & $-/+$ \\
\hline *Talaromyces flavus & $+/+$ & $+/+$ & $-1-$ & $+/+$ \\
\hline * Talaromyces ohiensis & $-1-$ & $+/+$ & $-1-$ & $-1-$ \\
\hline GU092968 Talaromyces striatus 100\% & $+/+$ & $+/+$ & $+/+$ & $+/+$ \\
\hline * Talaromyces thermophilus & $-/+$ & $-/-$ & $-1-$ & $-1-$ \\
\hline * Talaromyces trachyspermus & $-/+$ & $-1-$ & $-1-$ & $-1-$ \\
\hline * Talaromyces wortmanii & $-1-$ & $-1-$ & $-1-$ & $+/+$ \\
\hline Trichoderma harzianum & $-1-$ & $-1-$ & $+/+$ & $+/+$ \\
\hline Trichoderma koningii & $+/+$ & $+/+$ & $+/+$ & $+/+$ \\
\hline
\end{tabular}


Table 4. Cont.

\begin{tabular}{ccccc}
\hline Genera/Species/Sequence Similarity & \multicolumn{3}{c}{ Localities } \\
\cline { 2 - 4 } & REF & EXT & NEX & FIR \\
\hline DQ845431 Trichoderma viride aggregate 100\% & $+/+$ & $+/+$ & $+/+$ & $+/+$ \\
\hline Verticillium lecani & $-/-$ & $+/+$ & $-/-$ & $-/-$ \\
\hline Zygorhynchus heterogamus & $+/+$ & $+/+$ & $+/+$ & $+/+$ \\
\hline Zygorhynchus moelleri & $+/+$ & $+/+$ & $+/+$ & $+/+$ \\
\hline
\end{tabular}

* heat-resistant species isolated after heat treatment of the samples; "+"-occurrence of the fungus; "- "-not occurrence of the fungus; REF-locality with intact forest; EXT-locality with extracted wood mass; NEX-locality with non-extracted wood mass; FIR-locality with burnt forest.

Up to now, 81 genera and 242 species of soil filamentous fungi had been described in the Dystric Cambisol in Slovakia [89]. In the current study, species of Aspergillus fischeri as Neosartorya fischeri, A. fischeri var. glaber as N. glabra, Cheatomium atrobrunneum, Geosmithia argillacea, Myxotrichum deflexum, Penicillium abidjanum as Eupenicillium abidjanum, P. alutaceum as E. alutaceum, P. inusitatum as E. inusitatum, P. indonesiae as E. erubescens and E. ludwigii, P. melanoforme as E. melanoforme, P. parvum as E. parvum, P. sclerotigenum, Piptocephalis lepidula, Scopulariopsis asperula, Talaromyces thermophilus, and Verticillium lecani were recorded from Slovakian Dystric Cambisol soils for the first time.

Mortierella alpina, M. bainieri, Mucor hiemalis $\mathrm{f}$. hiemalis and Trichoderma koningii are found most frequently in alpine environments, with similarities from 97 to 99\% [90]. Except for the Trichoderma species, the others (Mortierella, Mucor, or Rhizopus) were not present in our burnt plot. On the other hand, our results correspond well with those of Azaz and Pekel [85]. According to them, Aspergillus, Penicillium, Cladosporium, Trichoderma, and Chaetomium spp. usually dominate in burnt forest soils.

The diversity of communities seems to be a result of non-extreme conditions, stable conditions, evolutionary and successional time, and the kind of community developed in that time. The extent of differentiation of communities along habitat gradients is known as beta diversity [46]. Indexes of similarity or dissimilarity of fungal communities were determined according to Sørensen and Jaccard. As shown in Table 5, there is a low similarity between soil mycocoenoses in the locality with an intact forest ecosystem and the localities with extracted wood mass (REF-EXT 53.3\%) and non-extracted wood mass (REF-NEX 53.80\%). Mycocoenosis on the burnt locality (FIR) is not similar to any of the others. This means that the windthrow and subsequent extraction or non-extraction of wood mass did not affect the soil mycobiota or its development. However, the fire was a significant event. As shown by Leckie [91], burnt soils have proportionally more filamentous fungi, which may be related to heat-resistant propagules or recolonization by air-borne spores.

Table 5. Similarity of mycocoenosis according to Sørensen $\left(\mathrm{S}_{\mathrm{S}}\right)$ and Jaccard $\left(\mathrm{S}_{\mathrm{J}}\right)$ in \% in soils at monitored localities in the High Tatra Mountains.

\begin{tabular}{|c|c|c|c|c|}
\hline & REF & EXT & NEX & FIR \\
\hline REF & - & $\begin{array}{l}S_{S}=53.3 \\
S_{J}=36.4\end{array}$ & $\begin{array}{l}\mathrm{S}_{\mathrm{S}}=53.8 \\
\mathrm{~S}_{\mathrm{J}}=36.8\end{array}$ & $\begin{array}{l}\mathrm{S}_{\mathrm{S}}=50.0 \\
\mathrm{~S}_{\mathrm{J}}=33.3\end{array}$ \\
\hline EXT & $\begin{array}{l}\mathrm{S}_{\mathrm{S}}=53.3 \\
\mathrm{~S}_{\mathrm{J}}=36.4\end{array}$ & J & $\begin{array}{l}\mathrm{S}_{\mathrm{S}}=39.3 \\
\mathrm{~S}_{\mathrm{J}}=24.4\end{array}$ & $\begin{array}{l}\mathrm{S}_{\mathrm{S}}=20.6 \\
\mathrm{~S}_{\mathrm{J}}=11.5\end{array}$ \\
\hline NEX & $\begin{array}{l}\mathrm{S}_{\mathrm{S}}=53.8 \\
\mathrm{~S}_{\mathrm{J}}=36.8\end{array}$ & $\begin{array}{l}S_{S}=39.3 \\
S_{J}=24.4\end{array}$ & J & $\begin{array}{l}\mathrm{S}_{\mathrm{S}}=43.3 \\
\mathrm{~S}_{\mathrm{J}}=27.2\end{array}$ \\
\hline FIR & $\begin{array}{l}S_{S}=50.0 \\
S_{J}=33.3\end{array}$ & $\begin{array}{l}S_{S}=20.6 \\
S_{J}=11.5\end{array}$ & $\begin{array}{l}S_{S}=43.3 \\
S_{J}=27.2\end{array}$ & - \\
\hline
\end{tabular}

While aiming to investigate the influence of windthrows, as well as harvesting, on forest ecosystems, attention is obviously paid to forest management, disruption of the water cycle, global warming, and soil erosion. The soil microbial community structure has been slightly omitted from these considerations. Both wildfires and harvesting are important disturbances to the forest ecosystem, including its soil 
microbial communities. As stated by Grishkan [92], wildfire affected the soil microbiota distinctly and with a more pronounced effect than harvesting or windthrow. Gőmőryová et al. [93] studied soil microbial community responses to the windthrow in the High Tatras. Their analyses showed that the highest microbial activity and microbial biomass occurred at the burnt plot and found no distinct differences in microbial attributes between the extracted and non-extracted plots. Ten years after the calamity, significant differences in microbial characteristics were observed between the FIR and the other localities. The results indicate that, at a higher altitude, the effect of fire on soil microorganisms is stronger than that of removing or not removing fallen trees, and can persist even over a decade.

Wildfire may cause several short- and long-term changes in the landscape and in soil environments inhabited by many fungi. The effects of fire on the soil mycobiota are highly variable and depend on many environmental factors, such as the type of soil and vegetation, fire intensity and soil enrichment by released nutrients $[22,51,94]$. Wildfires, as well as other means of soil warming or heating, form favourable conditions for the occurrence and growth of heat-resistant species and probably also result in the diminishment of many mesophilic microorganisms. This sort of die out releases organic matter and, simultaneously, results also in lowered competition from other microorganisms [56]. Fungi play the role of soil stabilizers and remediators after forest fires because of the formation of the mycelial mat functioning in soil particle aggregation. Some fire-surviving fungi also act as the post-fire fungi because they fruit only after exposure to fire, even though they may have formed mycorrhiza. They are pivotal microorganisms in the early recovery of the ecosystem after a fire, helping to minimize the movement of soil in a time of plant root absence [95].

\section{Conclusions}

The microbial consortia composition was examined, with a special focus on fungi, in various forest soil samples from four different localities by culture-independent high-throughput sequencing and culture-dependent approaches. The similarities and differences in microbiota composition were compared, with special attention to the most abundant taxa detected. The use of the HTS approach also allowed the detection of low abundance bacteria and fungi in the analysed soil samples. It was not possible to cultivate many of the most abundant taxa observed and identified by HTS. Therefore, it can be stated that the results of the two types of methods are complementary and reflect the much more complex reality.

Bacterial microbiota detected by HTS showed the prevalence of the genera Acidothermus (17.64\%), Mycobacterium (17.94\%), and Nocardia (5.53\%), and the very low presence of the genera Acidibacter (5.57\%), Burkholderia-Paraburkholderia (2.89\%), Optitus (1.62\%), and the uncultured genus Desulfurellaceae H16 $(3.38 \%)$ in the soil sample from the burnt locality (FIR) when compared to the other locations. In addition, soil mycocoenosis showed a low similarity between the localities with an intact forest ecosystem and the locality with extracted wood mass (REF-EXT), or non-extracted wood mass (RE-NEX), respectively. There was no similarity observed with the burnt locality (FIR), where heat-resistant filamentous fungi dominated.

Based on our results, the windthrow and subsequent extraction or non-extraction of wood mass did not radically affect the soil microbial communities and their development. On the other hand, the influence of fire was significant.

This investigation has contributed to the creation of a coherent picture of the overall soil microbial composition in the High Tatras and could be helpful in determining the further treatment of the forest after windthrows and the changes in soil microbiota after fires. The microbiome forms the base for the development of different ecosystems, even under dramatically changed or extreme conditions. Thanks to the high adaptability of the microbiome to extreme conditions, certain regeneration of biotic communities towards ecologic homeostasis is still possible.

Author Contributions: A.Š., E.P. (Elena Piecková), M.G., J.G. and E.P. (Eva Pauditšová) design the study and performed the sampling. A.Š., E.P. (Elena Piecková), M.G., J.G. have isolated and preliminary identified the fungal strains. L.K. identified the fungal isolates by molecular approach. D.P. designed the next generation sequencing 
experimentation. L.K. and K.Š. performed the next generation sequencing analysis. J.B., T.S., K.Š. and M.P. carried out the bioinformatics investigation. M.P., A.Š. and D.P. wrote the manuscript. All authors discussed the results and commented on the manuscript.

Funding: The work was supported by the Slovak National Grant Agency, projects VEGA 1/0424/18 and VEGA 1/0658/19.

Conflicts of Interest: The authors declare that they have no conflict of interest.

\section{References}

1. Perry, D.A.; Oren, R.; Hart, C. Forest Ecosystems; Johns Hopkins University Press: Baltimore, MD, USA, 2008.

2. Emerton, L.; Bishop, J.; Thomas, L. Sustainable Financing of Protected Areas: A Global Review of Challenges and Options; IUCN: Gland, Switzerland; Cambridge, UK, 2006; 97p.

3. Füssel, H.M.; Klein, R.J.T. Climate change vulnerability assessments: An evolution of conceptual thinking. Clim. Chang. 2006, 75, 301-329. [CrossRef]

4. Lindner, M.; Maroschek, M.; Netherer, S.; Kremer, A.; Barbati, A.; Garcia-Gonzalo, J.; Seidl, R.; Delzon, S.; Corona, P.; Kolstro, M.; et al. Climate change impacts, adaptive capacity, and vulnerability of European forest ecosystems. For. Ecol. Manag. 2010, 259, 698-709. [CrossRef]

5. Goetz, S.J.; Bond-Lamberty, B.; Law, B.E.; Hicke, J.A.; Huang, C.; Houghton, R.A. Observations and assessment of forest carbon dynamics following disturbance in North America. J. Geophys. Res. Biogeosci. 2012, 117, 1-17. [CrossRef]

6. Seidl, R.; Rammer, W.; Blennow, K. Simulating wind disturbance impacts on forest landscapes: Tree-level heterogeneity matters. Environ. Model. Softw. 2014, 51, 1-11. [CrossRef]

7. European Environment Agency. European Forest Ecosystems State and Trends; EEA Report No 5/2016; Publications Office of the European Union: Luxembourg, 2016.

8. San-Miguel-Ayanz, J.; Durrant, T.; Boca, R.; Libertà, G.; Branco, A.; de Rigo, D.; Ferrari, D.; Maianti Vivancos, T.A.; Costa, H.; Lana, F.; et al. Forest Fires in Europe, Middle East and North Africa 2017; Joint Research Centre-Technical Reports; European Commission: Ispra, Italy, 2017; 142p. [CrossRef]

9. González-Pérez, J.A.; González-Vila, J.F.; Almendros, G.; Knicker, H. The effect of fire on soil organic matter-A review. Environ. Int. 2004, 30, 855-870. [CrossRef]

10. Rousk, J.; Bengtson, P. Microbial regulation of global biogeochemical cycles. Front. Microbiol. 2014, 5, 103. [CrossRef]

11. Hartmann, A.; Kobler, J.; Kralik, M.; Dirnböck, T.; Humer, F.; Weiler, M. Model-aided quantification of dissolved carbon and nitrogen release after windthrow disturbance in an Austrian karst system. Biogeoscience 2016, 13, 159-174. [CrossRef]

12. Kramer, K.; Brang, P.; Bachofen, H.; Bugmann, H.; Wohlgemuth, T. Site factors are more important than salvage loggingfor tree regeneration after wind disturbance in Central European forests. For. Ecol. Manag. 2014, 331, 116-128. [CrossRef]

13. Logue, J.B.; Findlay, S.E.G.; Comte, J. Editorial: Microbial Responses to Environmental Changes. Front. Microbiol. 2015, 6, 1364. [CrossRef]

14. Falt'an, V.; Bánovský, M.; Blažek, M. Evaluation of land cover changes after extraordinary windstorm by using the land cover metrics: A case study on the High Tatras foothill. Geografie 2011, 116, 156-171.

15. Strelcová, K. Risk Assessment of the Tatra Mountains Forest. In Bioclimatology and Natural Hazards; Strelcová, K. Springer: Berlin/Heidelberg, Germany, 2009; pp. 145-154.

16. Jonášová, M.; Vávrová, E.; Cudlín, P. Western Carpathian mountain spruce forest after a windthrow: Natural regeneration in cleared and uncleared areas. For. Ecol. Manag. 2010, 259, 1127-1134. [CrossRef]

17. Fleisher, P.; Homolová, Z. Tatra Mts. As the objects for long-term ecological research of natural disturbances. Životné Prostredie 2016, 50, 40-43. (In Slovak)

18. Fleisher, P.; Homolová, Z. Long-term research on ecological conditions in the larch-spruce forests in High Tatras after natural disturbances. Lesn. Čas. For. J. 2012, 57, 237-250. (In Slovak)

19. Fleischer, P.; Pichler, V.; Fleischer, P., Jr.; Holko, L.; Gőmőryová, E.; Mális, F.; Cudlín, P.; Holeksa, J.; Michalová, Z.; Homolová, Z.; et al. Forest ecosystem services affected by natural disturbances, climate and land-scape changes in the Tatra Mountains. Clim. Res. 2017, 73, 57-71. [CrossRef] 
20. Šimkovic, I.; Dlapa, P.; Šimonovičová, A.; Ziegler, W. Water repellency of mountain forest soils in relation to impact of the katabatic windstorm and subsequent management practices. Pol. J. Environ. Stud. 2009, 18, 443-454.

21. Gáfriková, J.; Hanajík, P.; Zvarík, M. Determination of organic fractions and enzymatic activity in forest spruce soil of Tatra National Park. Ekológia Bratisl. 2018, 37, 328-337.

22. Gőmőryová, E.; Fleischer, P.; Gömöry, D. Soil microbial community responses to windthrow disturbance in Tatry National Park (Slovakia) during the period 2006-2013. Lesn. Cas. For. J. 2014, 60, 137-142. [CrossRef]

23. Hanajík, P.; Gáfriková, J.; Zvarík, M. Dehydrogenase activity in topsoil at windthrow plots in Tatra national Park. Cent. Eur. J. 2017, 63, 91-96. [CrossRef]

24. Homolová, Z.; Kyselová, Z.; Šoltés, R. Dynamics of vegetation on calamity areas in plant community of Lariceto-Piceetum. Stud. Tatra Natl. Park 2015, 11, 183-191. (In Slovak)

25. Zielonka, T.; Holeksa, J.; Fleischer, P.; Kapusta, P. A tree-ring reconstruction of wind disturbances in a forest of the Slovakian Tatra Mountains, Western Carpathians. J. Veg. Sci. 2010, 21, 31-42. [CrossRef]

26. Urbanovičová, V.; Miklisová, D.; Kováč, L. The effect of windthrow, wild fire, and management practices on epigeic Collembola in windthrown forest stands of the High Tatra Mts. (Slovakia). Biológia 2013, 68, 941-949. [CrossRef]

27. Mitchell, S.J. Wind as a natural disturbance agent in forests: A synthesis. Forestry 2013, 86, 147-157. [CrossRef]

28. Hrivnáková, K.; Makovníková, J.; Barančí;ková, G.; Bezák, P.; Bezáková, Z.; Dodok, R.; Grečo, V.; Chĺpik, J.; Kobza, J.; Lištjak, M.; et al. Unified Working Procedures of Soil Analyses; Výskumný ústav pôdoznalectva a ochrany pôdy (Research Institute of Pedology and Soil Protection): Bratislava, Slovak, 2011; 136p. (In Slovak)

29. Zbíral, J.; Honsa, I. Soil Analysis; Ústřední kontrolní a zkušební ústav zemědelský, Národní referenční laboratoř (Central Control and Analytical Agroinstitute, National Reference Laboratory): Brno, Czech, 2010; 230p. (In Czech)

30. Bolger, A.M.; Lohse, M.; Usadel, B. Trimmomatic: A flexible trimmer for Illumina sequence data. Bioinformatics 2014, 30, 2114-2120. [CrossRef] [PubMed]

31. Andrews, S. FastQC: A quality control tool for high throughput sequence data. 2010. Available online: http://www.bioinformatics.babraham.ac.uk/projects/fastqc (accessed on 12 December 2018).

32. Xu, H.; Luo, X.; Qian, J.; Pang, X.; Song, J.; Qian, G.; Chen, J.; Chen, S. FastUniq: A fast de novo duplicates removal tool for paired short reads. PLoS ONE 2012, 7, e52249. [CrossRef] [PubMed]

33. Quast, C.; Pruesse, E.; Yilmaz, P.; Gerken, J.; Schweer, T.; Yarza, P.; Peplies, J.; Glöckner, F.O. The SILVA ribosomal RNA gene database project: Improved data processing and web-based tools. Nucleic Acids Res. 2012, 41, 590-596. [CrossRef]

34. Bengtsson-Palme, J.; Hartmann, M.; Eriksson, K.M.; Pal, C.; Thorell, K.; Larsson, D.G.J.; Nilsson, R.H. METAXA2: Improved identification and taxonomic classification of small and large subunit rRNA in metagenomic data. Mol. Ecol. Resour. 2015, 15, 1403-1414. [CrossRef]

35. Miller, C.S.; Baker, B.J.; Thomas, B.C.; Singer, S.W.; Banfield, J.F. EMIRGE: Reconstruction of full-length ribosomal genes from microbial community short read sequencing data. Genome Biol. 2011, 12, 44. [CrossRef]

36. Kõljalg, U.; Larsson, K.H.; Abarenkov, K.; Nilsson, R.H.; Alexander, I.J.; Eberhardt, U.; Erland, S.; Høiland, K.; Kjøller, R.; Larsson, E.; et al. UNITE: A database providing web-based methods for the molecular identification of ectomycorrhizal fungi. New Phytol. 2005, 166, 1063-1068. [CrossRef]

37. Ondov, B.D.; Bergman, N.H.; Phillippy, A.M. Interactive metagenomic visualization in a Web browser. BMC Bioinform. 2011, 12, 385. [CrossRef]

38. Pedregosa, F.; Varoquaux, G.; Gramfort, A.; Michel, V.; Thirion, B.; Grisel, O.; Blondel, M.; Prettenhofer, P.; Weiss, R.; Dubourg, V.; et al. Scikit-learn: Machine learning in Python. J. Mach. Learn. Res. 2011, 12, 2825-2830.

39. Samson, R.A.; Hoekstra, E.S.; Frisvad, J.C.; Filtenborg, O. Introduction to Food-Borne Fungi, 5th ed.; Centraalbureau voor Schimmelcultures: Baarn, The Netherlands, 1996.

40. Pitt, J.I. The Genus Penicillium and Its Teleomorphic States Eupenicillium and Talaromyces; Academic Press: London, UK, 1979.

41. De Hoog, G.S.; Guarro, J.; Gené, J.; Figueras, M.J. Atlas of Clinical Fungi; Centraalbureau voor Schimmelcultures: Baarn and Delft, The Netherlands; Universitat Rovira i Virgili: Reus, Spain, 2000.

42. Samson, R.A.; Frisvad, J.C. Penicillium Subgenus Penicillium: New Taxonomic Schemes and Mycotoxins and Other Extrolites; Centraalbureau voor Schimmelcultures: Utrecht, The Netherlands, 2004. 
43. Domsch, K.H.; Gams, W.; Anderson, T.H. Compendium of Soil Fungi, 2nd ed.; taxonomically revised by Walter Gams; IHW-Verlag: Eching, Germany, 2007.

44. Hubka, V. Taxonomic revision of Eurotium and transfer of species to Aspergillus. Mycologia 2013, 105, 912-937. [CrossRef] [PubMed]

45. Visagie, C.M.; Houbraken, J.; Frisvad, J.C.; Hong, S.B.; Klaassen, C.H.W.; Perrone, G.; Seifert, K.A.; Varga, J.; Yaguchi, T.; Samson, R.A. Identification and nomenclature of the Penicillium. Study Mycol. 2014, 78, 343-371. [CrossRef] [PubMed]

46. Whittaker, R.H. Evolution and measurement of species diversity. TAXON 1972, 21, 213-251. [CrossRef]

47. Ramírez, J.S.; Hoyos, V.C.; Guido Plaza, T. Phytosociology of weeds associated with rice crops in the department of Tolima, Colombia. Agron. Colomb. 2015, 33, 64-73. [CrossRef]

48. WRB-World Reference Base for Soil Resources. A Framework for International Classification, Corelation and Communication; FAO-ISRIC-ISSS: Rome, Italy, 2006.

49. Fernandéz-Delgado Juárez, M.; Gómez-Brandón, M.; Knapp, A.; Stöhr, D.; Insam, H. Chemical and microbiological properties of alpine forest soils: Effects of pelletizatized ashes in a short-term trial. For. Ecol. Manag. 2015, 357, 42-49. [CrossRef]

50. Santin, C.; Doerr, S.H. Fere effect on soils: The human dimension. Philos. Trans. R. Soc. B Biol. Sci. 2016, 371, 20150171. [CrossRef] [PubMed]

51. Zavala, L.M.; De Celis, R.; Jordán, A. How wildfires affect soil properties. A brief review. CIG 2014, 40, 311-331.

52. Bogunovic, I.; Kisic, I.; Jurisic, A. Influence of wildfire and fire suppression by seawater on soil properties. Appl. Ecol. Environ. Res. 2015, 13, 1157-1169. [CrossRef]

53. Heydari, M.; Rostamy, A.; Naajafi, F.; Dey, D.C. Effect of fire severity on physical and biochemical soil properties in Zagros oak (Quercus brantii Lindt.) forests in Iran. J. For. Res 2017, 28, 95-104. [CrossRef]

54. Xue, L.; Qiujing, L.; Hongyue, C. Effects of a wildfire on selected physical, chemical and biochemical soil properties in a Pinus massoniana forest in south China. Forests 2014, 5, 2947-2966. [CrossRef]

55. Hanajík, P.; Šimonovičová, A.; Piecková, E.; Jesenák, K. Monitoring of pedochemical and microbiological changes at the selected localities in the High Tatras after windstorm calamity Nov 2004, 19. Štúdie o Tatranskom národnom parku (Stud. Tatra Natl. Park) 2009, 9, 42, 199-206.

56. Šimonovičová, A.; Nováková, A.; Pangallo, D.; Hnátová, V. The occurrence of heat-resistant species of Trichophaea abundans in different types of soil in Slovakia and Czech Republic. Biológia 2014, 69, 168-172. [CrossRef]

57. Berry, A.M.; Barabote, R.D.; Normand, P. The Family Acidothermaceae. In The Prokaryotes, 4th ed.; Rosenberg, E., De Long, E.F., Lory, S., Stackebrandt, E., Thompson, F., Eds.; Springer: Berlin/Heidelberg, Germany, 2014; pp. 13-19.

58. Mohagheighi, A.; Grohmann, K.; Himmel, M.; Leighton, L.; Updegraff, D.M. Isolation and Characterization of Acidothermus cellulolyticus gem nov.; sp. nov.; a new genus of thermophilic, acidophilic, cellulolytic bacteria. Int. J. Syst. Bacteriol. 1986, 36, 435-443. [CrossRef]

59. Barbarote, R.D.; Xie, G.; Leu, D.H.; Normand, P.; Nesculea, A.; Daubin, V.; Médigue, C.; Adney, W.S.; Xu, X.C.; Lapidus, A.; et al. Complete genome of the cellulolytic thermophile Acidothermus cellulolyticus 11B provides insights into its ecophysiological and evolutionary adaptations. Genome Res. 2009, 19, 1033-1043. [CrossRef] [PubMed]

60. Mikita-Barbatoa, R.A.; Kelly, J.J.; Tate, R.L. Wildfire effects on the properties and microbial community structure of organic horizon soils in the New Jersey Pinelands. Soil Biol. Biochem. 2015, 86, 67-76. [CrossRef]

61. Leys, N.M.; Ryngaert, A.; Bastiaens, L.; Wattiau, P.; Top, E.M.; Verstraete, W.; Springael, D. Occurrence and community composition of fast-growing Mycobacterium in soils contaminated with polycyclic aromatic hydrocarbons. FEMS Microbiol. Ecol. 2005, 51, 375-388. [CrossRef] [PubMed]

62. Cobo-Díaz, J.F.; Fernández-González, A.J.; Villadas, P.J.; Robles, A.B.; Toro, N. Metagenomic assessment of the potential microbial nitrogen pathways in the rhizosphere of a Mediterranean forest after a wildfire. Microb. Ecol. 2015, 69, 895-904. [CrossRef]

63. Bárcenas-Moreno, G.; García-Orenes, F.; Mataix-Solera, J.; Mataix-Beneyto, J.; Bååth, E. Soil microbial recolonisation after a fire in a Mediterranean forest. Biol. Fert. Soils 2011, 47, 261-272. [CrossRef] 
64. Yeager, C.M.; Northup, D.E.; Grow, C.C.; Barns, S.M.; Kuske, C.R. Changes in nitrogen-fixing and ammonia-oxidizing bacterial communities in soil of a mixed conifer forest after wildfire. Appl. Environ. Microbiol. 2005, 71, 2713-2722. [CrossRef]

65. Wang, N.F.; Zhang, T.; Zhang, F.; Wang, E.T.; He, J.F.; Ding, H.; Zhang, B.T.; Liu, J.; Ran, X.B.; Zang, J.Y. Diversity and structure of soil bacterial communities in the Fildes Region (maritime Antarctica) as revealed by 454 pyrosequencing. Front. Microbiol. 2015, 6. [CrossRef]

66. Famintzin, A. Eine neue Bacterienform: Nevskia ramosa. Bull. Acad. Sci. St Petersburgh New Ser. 1892, 2, 481-486.

67. Leandro, T.; França, L.; Nobre, M.F.; Schumann, P.; Rosselló-Móra, R.; da Costa, M.S. Nevskia aquatilis sp. nov. and Nevskia persephonica sp. nov.; isolated from a mineral water aquifer and the emended description of the genus Nevskia. Syst. Appl. Microbiol 2012, 35, 297-301. [CrossRef] [PubMed]

68. Weon, H.Y.; Kim, B.; Son, J.A.; Song, M.H.; Kwon, S.W.; Go, S.J.; Stackebrandt, E. Nevskia soli sp. nov.; isolated from soil cultivated with Korean ginseng. Int. J. Syst. Evol. Microbiol 2008, 1188, 578-580. [CrossRef] [PubMed]

69. Kim, S.J.; Weon, H.; Kim, Y.S.; Park, I.C.; Son, J.A.; Kwon, S.W. Nevskia terrae sp. nov.; isolated from soil. Int. J. Syst. Evol. Microbiol 2011, 61, 1226-1229. [CrossRef] [PubMed]

70. Green, S.J.; Prakash, O.; Jasrotia, P.; Overholt, W.A.; Cardenas, E.; Hubbard, D.; Tiedje, J.M.; Watson, D.B.; Schadt, C.W.; Brooks, S.C.; et al. Denitrifying bacteria from the genus Rhodanobacter dominate bacterial communities in the highly contaminated subsurface of a nuclear legacy waste site. Appl. Environ. Microbiol. 2011, 78, 1039-1047. [CrossRef] [PubMed]

71. Rosling, A.; Cox, F.; Cruz-Martinez, K.; Ihrmark, K.; Grelet, G.A.; Lindahl, B.D.; Menkis, A.; James, T.Y. Archaeorhizomycetes: Unearthing an ancient class of ubiquitous soil fungi. Science 2011, 333, 876-879. [CrossRef]

72. Choma, M.; Bárta, J.; Šantrůčková, H.; Urich, T. Low abundance of Archaeorhizomycetes among fungi in soil metatranscriptomes. Sci. Rep. 2016, 6. [CrossRef]

73. Vaartaja, O. Pythium and Mortierella in soils of Ontario forest nurseries. Can. J. Microbiol. 1968, 14, $265-269$. [CrossRef]

74. Wagner, L.; Stielow, B.; Hoffmann, K.; Petkovits, T.; Papp, T.; Vágvölgyi, C.; de Hoog, G.S.; Verkley, G.; Voigt, K. A comprehensive molecular phylogeny of the Mortierellales (Mortierellomycotina) based on nuclear ribosomal DNA. Persoonia 2013, 30,77-93. [CrossRef]

75. Štursová, M.; Šnajdr, J.; Cajthaml, T.; Bárta, J.; Šantrůčková, H.; Baldrian, P. When the forest dies: The response of forest soil fungi to a bark beetle-induced tree dieback. ISME J. 2014, 8, 1920-1931. [CrossRef]

76. Rayner, A.D.M.; Todd, N.K. Population and community structure and dynamics of Fungi in decaying wood. Adv. Bot. Res. 1980, 7, 333-420. [CrossRef]

77. González, A.E.; Martínez, A.T.; Almendros, G.; Grinbergs, J. A study of yeasts during the delignification and fungal transformation of wood into cattle feed in Chilean rain forest. Antonie Van Leeuwenhoek 1989, 55, 221-236. [CrossRef] [PubMed]

78. Ramirez, C.; González, A. Candida santjacobensis and Candida ancudensis two new species of yeasts isolated from decayed wood in the evergreen rainy Valdivian forest of Southern Chile. Mycopathologia 1984, 88, 105-109. [CrossRef]

79. Yurkov, A. Yeasts in Forest Soils. In Yeasts in natural ecosystems: Diversity; Buzzini, P., Lachance, M.A., Yurkov, A., Eds.; Springer: Berlin/Heidelberg, Germany, 2017; pp. 87-116.

80. Buée, M.; Reich, M.; Murat, C.; Morin, E.; Nilsson, R.H.; Uroz, S.; Martin, F. 454 Pyrosequencing analyses of forest soils reveal an unexpectedly high fungal diversity. New Phytopathol. 2009, 184, 449-456. [CrossRef] [PubMed]

81. Hagerman, S.M.; Jones, M.D.; Bradfield, G.E.; Gillespie, M.; Durall, D.M. Effects of clear-cut logging on the diversity and persistence of ectomycorrhizae at a subalpine forest. Can. J. For. Res. 1999, 29, 124-134. [CrossRef]

82. Hartmann, M.; Howes, C.G.; Van Insberghe, D.; Yu, H.; Bachar, D.; Christen, R.; Nilsson, R.H.; Hallam, S.J.; Mohn, W.W. Significant and persistent impact of timber harvesting on soil microbial communities in Northern coniferous forests. ISME J. 2012, 6, 2199-2218. [CrossRef]

83. Štursová, M.; Žifčáková, L.; Leigh, M.B.; Burgess, R.; Baldrian, P. Cellulose utilization in forest litter and soil: Identification of bacterial and fungal decomposers. FEMS Microbiol. Ecol. 2012, 80, 735-746. [CrossRef] 
84. Voří̌̌ková, J.; Brabcová, V.; Cajthaml, T.; Baldrian, P. Seasonal dynamics of fungal communities in a temperate oak forest soil. New Phytol. 2013, 201, 269-278. [CrossRef]

85. Azaz, A.D.; Pekel, O. Comparison of soil fungi in burnt and unburnt forest soils in the vinicity of Kargicak (Alanya, Turkey). Turk. J. Bot. 2002, 26, 409-416.

86. Widden, P.; Parkinson, D. The effects of a forest fire on soil microfungi. Soil Biol. Biochem. 1975, 7, $125-138$. [CrossRef]

87. Geml, J.; Taylor, D.L. Biodiversity and molecular ecology of Russula and Lactarius in Alaska based on soil and sporocarp DNA sequences. Scr. Bot. Belg. 2013, 51, 132-145.

88. Early, R. Pathogen control in primary production: Crop foods. In Foodborne Pathogens Hazards, Risk Analysis and Control, 2nd ed.; Blackburn, C.W., McClure, P.J., Eds.; Woodhead Publishing Series in Food Science, Technology and Nutrition; Woodhead: Sawston, UK, 2009; pp. 205-279.

89. Šimonovičová, A. Biodiversity of Microscopic Fungi in Soil Types of Slovakia, 1st ed.; Comenius University in Bratislava: Bratislava, Slovakia, 2013.

90. Zhang, J.; Man, B.; Fu, B.; Liu, L.; Han, C. The diversity of soil culturable fungi in the three alpine shrub grassland of eastern Qilian Mountains. Front. Earth Sci. 2013, 7, 76-84. [CrossRef]

91. Leckie, S.E. Methods of microbial community profiling and their application to forest soils. For. Ecol. Manag. 2005, 220, 88-106. [CrossRef]

92. Grishkan, I. Influence of wildfire on diversity of culturable soil microfungal communities in the Mount Carmel forest, Israel. Plant Biosyst. Int. J. Deal. All Asp. Plant Biol. 2014, 150, 1-10. [CrossRef]

93. Gőmőryová, E.; Fleischer, P.; Pichler, V.; Homolák, M.; Here, R.; Gőmőry, D. Soil microorganisms at the windthrow plots: The effect of post-disturbance management and the time since disturbance. iForest 2017, 10, 515-521. [CrossRef]

94. Reazin, C.; Morris, S.; Smith, J.E.; Cowan, A.D.; Jumpponen, A. Fires of differing intensities rapidly select distinct soil fungal communities in a Northwest US ponderosa pine forest ecosystem. For. Ecol. Manag. 2016, 377, 118-127. [CrossRef]

95. Claridge, A.W.; Trappe, J.M.; Hansen, K. Do fungi have a role as soil stabilizers and remediators after forest fire? For. Ecol. Manag. 2009, 257, 1063-1069. [CrossRef]

(C) 2019 by the authors. Licensee MDPI, Basel, Switzerland. This article is an open access article distributed under the terms and conditions of the Creative Commons Attribution (CC BY) license (http://creativecommons.org/licenses/by/4.0/). 